\title{
Etnografías del amor: lugares literarios y argumentos para la ficción
}

\author{
JULIÁN LÓPEZ GARCía \\ Dpto. de Ciencias Sociales y Humanidades \\ Universidad de Córdoba
}

\section{RESUMEN}

Este ensayo se adentra en las formas de relación entre ficción literaria y realidad, partiendo de la convicción de que éstas son recíprocas. A partir del análisis de cartas entre novios en tres momentos diferentes de los dos últimos siglos, el autor aborda distintas maneras de la interacción. ¿Cómo se influyen ficción y realidad? ¿En qué circunstancias la acción de una sobre otra puede ser más intensa? Fundamentalmente, el autor se interesa por los mecanismos recíprocos de apropiación entre cultura letrada y cultura popular.

Palabras clave: Literatura, Metaliteratura, Cultura popular, Apropiación simbólica, Etnografía del amor.

\section{SUMMARY}

The author discusses the forms of relationship between literary fiction and reality, on the assumption that one interacts with the other. By analyzing a number of love letters that date to three different periods of the past two centuries, he delves into the various ways in which such interaction manifests itself. How do fiction and reality influence each other? Under what circumstances can the action of one be more intense on the other? The author's chief interest lies in the reciprocal mechanisms of appropriation between learned culture and popular culture.

Key words: Literature, Metaliterature, Popular Culture, Symbolic Appropriation, Ethnography of Love.

\section{SOBRE LA TRANSITIVIDAD DE LA LITERATURA}

En el proceso de consolidación de su método etnoliterario Manuel de La Fuente trataba de asentar no tanto cómo la vida cotidiana se expresa en la literatura, sino más bien cómo construye realidad; cómo la literatura, especialmente la novela, es un método etnográfico que permite dilucidar la manera que tiene la realidad de construirse a partir de la fantasía

RDTP, LX, 1 (2005): 217-267 
y el parecer. Puso énfasis, además, en verificarlo en aquellos aspectos que para él eran el nudo gordiano de la condición humana, a saber: el dolor, el sufrimiento, la vejez, la muerte y el paso del tiempo. Después de caminar por modelos filosóficos de abordaje de la condición humana volvía, al final de su vida, desde la literatura, a la esencia de la cita de Bachelard que inspiraba desde tiempo atrás su preocupación: "se comprenderá de otro modo y se sentirá de otro modo" (en de La Fuente 1979: 81).

En el momento de su muerte estaba pasando a retirar los lastres del cauteloso arranque en esa senda etnoliteraria (1995: 6) y estaba comenzando a buscar apoyos intelectuales y complicidades entre investigadores que abordasen, aunque tangencialmente, el asunto. En su afán de atracción llegó a incluir en el grupo de afines a Foucault a partir de una referencia muy posiblemente errada, que James Clifford atribuye, en la introducción a Retóricas de la Antropologia, al filósofo francés: "la literatura, en sí misma, es una categoría trascendental de la investigación científica" (1991: 31). En realidad Foucault representaba la posición opuesta a la que defendía Manuel de la Fuente. En una entrevista publicada por el diario El País, el 11 de septiembre de 1986, afirmaba que la literatura debería ser el..."objeto de una constante, no de un análisis ni de una reducción", de manera que no deseaba ver los textos literarios como expresivos o reflejo de proceso históricos; "la literatura - decía - parece valer para todo. La gente ha hecho historia con lo que se decía en el siglo XVIII pasando por Fonteneille o Diderot o Voltaire o la Nueva Eloísa, etcétera, e incluso consideraba tales textos como expresión de algo que finalmente no llegaba a formularse a un nivel que hubiera sido más cotidiano"; en cambio reivindica el valor como fuente de los "discursos no literarios o paraliterarios que se hayan podido elaborar en un época excluyendo de entre ellos la literatura. En Vigilar y castigar sólo trato la mala literaturan. En definitiva, para él aLa literatura no tiene que ocuparse más que de sí misman. Lo esencial es la importancia de este principio: la intransitividad de la literatura. En efecto esta fue la primera etapa, gracias a la cual "pudimos desembarazarnos de la idea de que la literatura era el lugar de todos los peajes, el punto al que todos los pasajeros llegaban, la expresión de las totalidades".

Muchos de los buenos debates se plantean a partir de posturas extremas, y aquí las hay: la literatura como método para desentrañar la condición humana frente a la literatura como fin en sí misma. En este artículo tercio y, como aprendiz, nadando en las aguas tranquilas de las posiciones intermedias. No obstante, aun valorando la reciprocidad en la relación entre literatura y vida cotidiana, refiero cómo en unos momentos una de las instancias puede sobrepasar a la otra y refiero también cuáles 
son algunos de los mecanismos de apropiación y trasvase de elementos de una de las instancias a la otra. Al querer ir más allá de la simple crítica a la univocidad (representada en las proposiciones: "vida popular como motivo literario" o "la literatura como modelo para la vida"), quiero entrar en las cualidades cambiantes de la relación. Lo haré a partir de otros elementos, a mi juicio también gordianos, de la condición humana, me refiero al vínculo socio-afectivo de pareja y concretamente al tema del cariño, el amor y la fidelidad en este átomo de parentesco. Me basaré en tres relaciones epistolares de pareja, separadas cada una de ellas por un siglo: cuatro cartas de Manuel Ribera a su novia Juana Carneros, enviadas entre septiembre de 1788 y febrero de 1789; sesenta y una tarjetas postales giradas entre Miguel Ripoll y Sebastiana Balaguer entre el verano de 1902 y el verano de 1903 y la frenética conversación electrónica que a lo largo de 6 horas ininterrumpidas mantienen, en 2001, los amantes Antonio y Susana, Pitusy y Pollamán nicks respectivos con los que entraron en el chat donde se conocieron.

\section{LA PALABRA DE CASAMIENTO: MOTIVO LITERARIO Y PLEITO SOCIAL}

Las nuevas deste lugar son que la Berrueca casó a su hija con un pintor de mala mano, que llegó a este pueblo a pintar lo que saliese; mandóle el concejo pintar las armas de su Majestad sobre las puertas del Ayuntamiento, pidió dos ducados, diéronselos adelantados, trabajó ocho días, al cabo de los cuales no pintó nada, y dijo que no acertaba a pintar tantas baratijas; volvió el dinero, y, con todo eso, se casó a título de buen oficial; verdad es que ya ha dejado el pincel y tomado el azada, y va al campo como gentilhombre. El hijo de Pedro de Lobo se ha ordenado de grados y corona, con intención de hacerse clérigo; súpolo Minguilla, la nieta de Mingo Silvato, y hale puesto demanda de que la tiene dada palabra de casamiento; malas lenguas quieren decir que ha estado encinta dél; pero él lo niega a pies juntillas.

Hogaño no hay aceitunas, ni se halla una gota de vinagre en todo este pueblo. Por aquí pasó una compañía de soldados; lleváronse de camino tres mozas deste pueblo; no te quiero decir quién son: quizá volverán, y no faltará quien las tome por mujeres, con sus tachas buenas o malas...

Tu mujer Teresa Panza.

Don Quijote de la Mancha, Capítulo LII.

En la primavera de 1789 comparece en el Juzgado de Almodóvar del Campo (Ciudad Real), Juana Carneros de 25 años de edad y "de estado honesto" y dice "que teniendo tratados esponsales con Manuel Rivera actual soldado del regimiento de Cavallería de voluntarios de España, como lo identifican las cartas que exivo [anexo 1] con prottestra de que se me devuelvan (fijada la notta o fe suficiente de su conttesto) Se estendio el 
afecto hasta tocar el estremo de conocerme carnalmente en ocasión de venir a esta villa, De que resultó quedar embarazada en cuio estado me hallo." Así para contrarrestar el efecto negativo que para su fama y honradez puede tener el hecho de que trasciendan "sus fragiliades", presenta cuatro cartas que le envía Manuel Rivera como prueba de que éste le dio palabra de casamiento.

En efecto la formalidad de la relación se comprueba ya en la primera de las cartas.

Herenzia y setienbre 29 de 1788

Muy señora mía y mi dueña e rrezibido la tuya y con ella mucho gusto por saber de tu salud la que yo disfruto es buena para lo que me quieras mandar pues deseo el que me mandes.

Muy señora mía me dizes que me despache con la lizencia del coronel, yo quisiera que ya estubiera aqui porque también yo lo deseo solo porque habla tanto la gente de la fe de viudo todo tan pronto como eso porque eso lo tengo yo en mi poder. Lo que hace a la lizencia del coronel ya le escribio el capitán para que me la de, veremos la rrespuesta que enbia porque lo mas que puede hacer es que añada cuatro años de servicio y que me case siendo con una muger de razón y bien nacida que nadie tenga que decir de ella ni de su gente porque a todas las mugeres que se an casado en el escuadron a sucedido lo mismo y asi en biniendo la razón del coronel beremos lo que habemos de acer. Daras mis espresiones a gregorio y a tia andrea y a felizia y tu las recibirás a medida de tu deseo. Dios te guarde muchos años quien más te estima que es tu M.R. Manuel Ribera.

Juana Carneros en la otra antecedente te dige que me embiaras a decir como estaban las casas de Corchado y no dizes nada.

Manuel reconoce que está haciendo el trámite necesario de pedir licencia para el casamiento pero no puede hacer él nada para adelantar los tiempos que se toman coronel y capitán para firmarla, aunque seguro de la concesión para poder casarse con "mujer de razón y bien nacida que nadie tenga que decir de ella ni de su genten. Para él es evidente que no habrá problema en ese extremo pues, como reconoce en la siguiente carta, entre ellos las diligencias están hechas. Usa el plural aunque se refiere más bien a que él conoce su fama y a su gente y de hecho les saluda y envía recuerdos en cada una de las cartas. ¿Y a la inversa? ¿él es fiable? La sucesión de costas y el desenlace de la historia (Juana tiene una niña y él no llegó a casarse) invitan a pensar que no. Ya en esta primera Manuel se refiere a la "fe de viudo" de la que habla tanto la gente, desde tan pronto. Cabe pensar que él es viudo o le ha dicho a Juana que lo es. Cabe pensar igualmente que Juana ha escuchado de la gente advertencias sobre la necesidad de que presente "fe de viudon; un desconocido, claro, debe dar fe de su soltería o de su condición de divorciado o viudo para poder casarse. Estamos entonces en presencia del 
motivo - literario y real- del soldado engañador. La procedencia lejana ya es indicio de engaño: el Marqués de Molins dio publicidad en La Manchega al aserto popular "quién de lejos se viene a casar o viene engañado o viene a engañar. Pero más en el soldado: va en su naturaleza errática y en su carisma construido. Aún sin conocer la literatura española de los siglos XVII y XVIII se puede fácilmente encontrar el motivo del soldado engañador, como en la Canción del olvido o en $A$ buen juez mejor testigo.

\begin{tabular}{|c|c|}
\hline $\begin{array}{l}\text { Convencida y conquistada, } \\
\text { en mi brazo se apoyó } \\
\text { y escuchaba mis embustes } \\
\text { llena de ilusión. } \\
\text { Al llevarla a su palacio, } \\
\text { mis finezas repetí: } \\
\text { "Dulce bien!" "Me engañáis." } \\
\text { "No acostumbro a mentir." } \\
\text { "¿Volveréis?" "CCómo no?" } \\
\text { "Va veré si fingís." } \\
\text { "Y dejándola ya, } \\
\text { de su amor me reí." } \\
\text { Canción del olvido. }\end{array}$ & $\begin{array}{l}\text { Diego, ¿juras a tu vuelta desposarme? Contestó el } \\
\text { mozo: } \\
\text { — ¡Sí, juro! } \\
\text { Pasó un día y otro día, un mes y otro mes pasó, y un } \\
\text { año pasado había; mas de Flandes no volvía Diego, } \\
\text { que a Flandes partió. } \\
\text { — ¿Hicisteisla juramento de ser su marido? } \\
\text { - No. } \\
\text { —-juráis no haberlo jurado? } \\
\text {-Sí juro. } \\
\text {-Pues id con Dios } \\
\text {-iMiente! - clamó Inés, llorando de despecho y de } \\
\text { rubor } \\
\text {-Mujer, ipiensa lo que dices! } \\
\text {-Digo que miente: juró. } \\
\text { A buen juez mejor testigo }\end{array}$ \\
\hline
\end{tabular}

Es cierto que parcialmente ese perfil del soldado traidor lo traza la literatura, pero no menos cierto es que la inspiración está, muchas veces, en sucesos reales. El engaño se interioriza como un arte más de conquista. Y la conquista - no la defensa - es el primer acto, la primera razón de ser del soldado en la España de la Edad Moderna. El arte de enamorar y el arte de la guerra caminan en paralelo, no pueden los manuales "de conquista" redactarse sin experiencias vividas y no pueden, tampoco, reacomodarse y perfeccionarse las tácticas sin asiento literario.

En la segunda carta se ve clara la estrategia de dar confianza por un lado y distanciarse por otro. Las palabras de Manuel hablan de constancia y permanencia, sus acciones, en cambio, van por el camino del repliegue y el olvido.

Herenzia 4 de enero de 1789

Muy señora mia me alegraré que esta te alle con la cabal salud que yo para mi deseo en compañía de las personas de tu mayor agrado la mia siempre para serbirte.

Muy señora mia Juana el motibo de no aberte escrito antes no a sido otra cosa más de aber estado en una partida fuera dos meses en busca de pringe e de benzeno, que Dios lea y de fe de como nos aze andar, no hay otra cosa en contra, que yo siempre soy uno y sin doblez y asi si piensas otra cosa estás mal entendida. De el mostillo que me dizes me as enbiado yo te lo agradezco mucho 
porque te acuerdas de mi pero yo no e rrecibido nada solo la esquela y eso con trabajos por aber marchado aquella misma tarde. No te respondí porque no se puede fiar nadie de sujetos semejantes y asi escribeme cuando quieras, que yo siempre soy uno. Sabrás como estoy nombrado para yr a malagón destacado y no se cuando será. Y con esto dios te guarde muchos años quien más te estima es tu amante Manuel ribera.

Juana Carneros

Darás mis memorias a tía andrea y a la felizia y tu las rezibirás duplicadas del yntimo de mi corazón

Sabemos que en la fecha de redacción de la carta Manuel ya conoce el embarazo de Juana, pues en la siguiente explícitamente dice que ha pasado malas pascuas pensando "en cosas"; posiblemente lo supo en la carta que Juana le envió junto con el mostillo a comienzos de noviembre. La carta comienza con la constatación de una larga ausencia: ha estado dos meses fuera en una partida buscando materia prima para explosivos. Termina con un aviso de una nueva ausencia: está nombrado para ir destacado a Malagón, aunque no sabe cuándo. En medio, junto a una concesión al cariño que ella le tiene y que él le agradece por el envío del mostillo, reiteradas manifestaciones para transmitir confianza: "yo siempre soy uno y sin doblez", hasta el punto de poner a Dios por notario, "que Dios lea y de fe de cómo nos hace andar que no hay otra cosa". La veracidad de sus intenciones de casarse llegan a formar parte de su esencia: ser uno, ser claro, no tener doblez... pero, sobre todo poner a Dios como garante de la veracidad de sus palabras y la determinación de su propósito. Garante o testigo, el protagonismo de Dios tiene extensión literaria con fama de su efectividad justiciera desde A buen juez mejor testigo. A la vista está, no obstante, que la fuerza del argumento literario no cala automáticamente en la vida real, de manera que aparece también como motivo literario el jurar en falso. Jurar y no cumplir, jurar incluso poniendo a Dios por testigo y no cumplir se presenta como un marcador de la vida cotidiana. Sin embargo, no es hasta la tercera carta cuando aparece la constancia del temor y la duda de Juana. Es una respuesta rápida a otra que ella le envía poco antes y en la que se podría apreciar cómo crece su impaciencia.

Herenzia y enero 25 de 1789

Muy señora mía He rrecibido la tuya y con ella mucho gusto por saber de tu salud la mia es buena para serbirte.

Juana de lo que me dizes de que no hago diligencia para nada, te digo que la diligenzia ya está echa, sólo que el coronel todabía no a respondido con nada ya dos o tres meses. Y mi capitán dize que es menester azer diligencias ynformaciones de quien tu eres como se an echo de las demás que se han casado en el escuadrón. Pero eso será cuando venga del coronel. Y ahora te digo que si tu has tenido 
malas pascuas yo no las e tenido muy buenas porque solo en pensar en cosas e tenido bastante; y así te digo que no te de cuydado de nada porque yo estoy en el mundo dispuesto a todo lo que dios me enbie. Me arás el fabor de enbiarme una poca de puntilla para dos camisas que me e echo y por aquí bale demasiado cara. Y con esto no te canso más. Dios te guarde muchos años. Darás memorias a gregorio y a tía Andrea y a Felizia y tu las rezibirás a medida de tu deseo quien más te estima y ber desea tu amante Manuel Ribera. Querida Juana Carneros.

Juana, no estés deconfiada de mí que yo no soy más que uno ni puedo serlo tampoco. Ya se sabrá quien soy yo, y no digo más.

Escribe a erenzia.

La misiva, complementaria de la anterior, se podría enmarcar dentro del género que podríamos llamar retóricas de la tranquilización: 1.o) no es culpa suya que esté demorándose la llegada de la licencia, 2.o) es consciente del estado de embarazo de Juana y tácitamente asume su responsabilidad; está preocupado y por eso ha tenido malas pascuas, 3.ํ) es consciente de que para ella la situación es especialmente problemática pero no debe preocuparse $\longrightarrow$ no te de cuidado de nada - , porque él no va a desdecirse de su compromiso, $4 .{ }^{9}$ ) admite, como no podía ser de otro modo, la voluntad de Dios: "yo estoy en el mundo dispuesto a todo lo que Dios me envíe" y no va hacer nada en contra para aceptar las dos cosas nuevas que Dios le envía: el matrimonio con Juana y el hijo que esperan, 5.9) luego, no hay razón para la desconfianza porque "yo no soy más que uno ni puedo serlon, es decir: Manuel tiene una sola palabra, 6.9 ) con todo, termina con una frase lapidaria e incontrovertible: el tiempo le dará la razón, "ya se sabrá quien soy yo". Dentro de las retóricas de la confianza se incluyen aditamentos de normalidad y de complicidad: en ese sentido la petición de puntilla para dos camisas que se ha hecho y, desde luego, la constancia en las fórmulas de saludo y despedida epistolar que, aunque responden a esquemas normalizados, no indican ningún cambio: él sigue mostrando cariño en la preocupación por su salud y sigue despidiéndose como "tu amante». Retóricas de la confianza las estoy llamando, retóricas en las que se incluye el poner a Dios como testigo en la carta antecedente y la referencia definitiva, escrita, a la palabra de casamiento que ha dado.

\section{Herenzia y 16 de febrero de 1789}

Juana y muy querida mía He rrezibido la tuya y con ella mucho gusto por saber de tu salud, la mía es buena para lo que me quieras mandar que lo are con mucho gusto.

Muy señora mia si $\mathrm{v}$ md se a enfadao por aber enbiado a dezir de las ynformaciones es lo que más procuran en esta tierra y la tropa que nosostros siempre las tenemos hechas y por eso me mandas a decir que si te di la palabra para no cumplirla, yo soy mas firme que las murallas de la plaza de gribaltar, pero me parece a ala contra que sabe dios quien será más firme. Me pareze muy 
mal que me andes con enredos de la puntilla, si la quieres enbiar te enbiaré el dinero para que no pienses que te pido nada, que poco pedigüeño soy yo. De la lizencia del capitán ya se a pedido, ya la enbio al coronel, pero la respuesta no a benido todabia y hasta que benga no podemos azer nada, ya ten paciencia hasta que Dios quiera. Y con esto no te canso más.

Dios te guarde muchos años quien más te estima y ber desea, tu querido Manuel Ribera.

Querida Juana Carneros darás mis memorias a la tia andrea y a felizia y a Gregorio y a la tia andrea que su sobrino Francisco Santos que ha sentado plaza otra vez en los boluntarios.

Rizibirás el alma mía y adiós y Dios te guarde.

Ay mi corazón

Esta cuarta y última carta representa el momento culminante, la intensidad y tensión mayor en la lucha entre la desconfianza e intranquilidad de Juana y la perseverancia de Manuel en ganarla. El esquema retórico de la lucha podemos plantearlo en forma de diálogo epistolar en paralelo, aunque no tengamos la carta de Juana. Escribo, entre corchetes, el sentido que podría tener: $1^{\circ}$ ) [Juana muestra su enfado e indignación porque Manuel le ha dicho que antes de la boda deben informarse en la tropa de quién es ella ¿será una estrategia de dilación de Manuel?], Manuel dice que es normal "es lo que más procuran en esta tierra y la tropa", no se trata dé que él dude de ella, por el contrario "nosotros siempre las tenemos hechas", es decir, entre ellos no hay duda de quién es

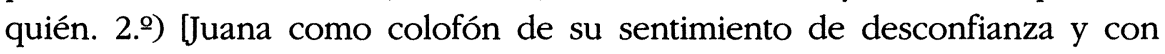
la desazón de comprobar que su embarazo avanza sin que se concrete el plan de boda, plantea ya la pregunta definitiva: ¿le dio la palabra de casamiento para no cumplirla?] Manuel adopta tono casi épico y le sale ese rasgo del perfil de soldado que lleva dentro, llegando al extremo de compararse con las murallas de la plaza de Gibraltar en defensa de su palabra e integridad: "yo soy más firme que las murallas de la plaza de Gibraltar" ${ }^{1}$. 3.ํ) [Juana manifiesta su enfado ante el intento de normalización de la relación que Manuel hace al pedirle la puntilla para las camisas: no da nada, no hace diligencias con la licencia... y encima le pide la puntilla para las camisas] Le toca a Manuel, dentro de esta estrategia, adoptar el papel de víctima incomprendida: le enviará el dinero "para que no pienses que te pido nada, que poco pedigüeño soy yo". 4.. ) [En ese contexto temático de pedir y no dar, Juana insiste en saber qué pasa con

\footnotetext{
${ }^{1}$ Después de la ocupación de Gibraltar en 1704 y tras un intento de liberación por parte de tropas hispano-francesas, la corona británica fortifica férreamente el territorio, hasta el punto de que el segundo sitio (entre 1727-1728) con 25.000 soldados también fracasa. El tercer y último sitio, en 1782, con 40.000 soldados y 39 navíos se levantó sin éxito en 1783.
} 
la petición de licencia] Manuel repite la retahíla del proceso y le pide "paciencia"; una petición de paciencia mayormente inconcreta, "hasta que Dios quiera. 5.9) Manuel se despide de una manera diferente y definitiva con un "Ay mi corazón.. Esta interjección es la última palabra que conocemos de Manuel y, como tal, es el clímax de la ambigüedad; la mejor manera de poner punto final a la relación, pues puede expresar sentimiento profundo y cariño, o lamento y adiós.

Se trata pues de dos escrituras/lecturas que caminan en paralelo, la del acercamiento y búsqueda de confianza, y de alejamiento y dilación. En la estrategia de la confianza la palabra de casamiento ocupa un lugar preeminente. Cabe preguntarse ¿cuál era a finales del s. XVIII su estatus social y literario? Con contundencia podemos decir que si hay un asunto que llena los archivos del s. XviII es el de las demandas por incumplimiento de la palabra de casamiento, desde Extremadura (Testón 1985) a Cataluña, desde Castilla (Mantecón Movellán 2002) a Canarias (Hernández González 1998), de Chile (Goicovic 1998) a la Nueva España. Y, por otro lado, si hay un asunto que satura el teatro del siglo de oro ese es el del honor, al que se vinculan el acto de dar (como paso fundamental en la conquista amorosa) y no cumplir (como actitud relativamente frecuente entre los hombres) la palabra de casamiento o de matrimonio, con los consiguientes pleitos sociales y morales que conlleva. Como ha señalado Igor Goicovic (1998: 32):

La práctica de relaciones sexuales durante el galanteo dependía en gran medida del intercambio de la palabra de casamiento, ésta constituía una obligación social y moral que nadie podía eludir y que, además, garantizaba que la entrega sexual estaba respaldada por la palabra empeñada [...] Como en esta lógica el proceso del matrimonio se iniciaba con la palabra de esponsales, la verificación de relaciones sexuales eran un hecho subsecuente. Con la entrega sexual de la novia la seducción ya estaba completa. Las alternativas posteriores quedaban relegadas a la voluntad del seductor, el cual podía optar entre el cumplimiento de la palabra empeñada y contraer nupcias, practicar indefinidamente una cohabitación o unión consensual o sencillamente desconocer el compromiso y abandonar a la seducida.

Esta última será una alternativa tanto más a tener en cuenta, en cuanto que la trascendencia social de la palabra de casamiento vaya decayendo. En buena medida el problema se plantea por un desajuste entre una práctica privada o casi privada (dar la palabra de casamiento, equivalía al mismo matrimonio) que tenía valor social y fuerza legal, y las nuevas ondas ritualistas post-trentinas que entronizan el matrimonio y arrinconan la palabra de casamiento. Desajuste porque la palabra de casamiento sigue teniendo, podríamos decir, fuerza carismática, pero decae la fuerza de la sanción moral y social por no cumplirla, pues ya en el s. xviII no equivale al matrimonio. 
Un repaso a los estudios de historia de las mentalidades en España del xviII en ese campo, refleja la recurrencia de pleitos por incumplimiento de palabra de casamiento. Una pequeña selección muestra, en distintos lugares, ese esquema de seducción y abandono, con el señuelo de la palabra de casamiento.

\begin{tabular}{|c|c|c|}
\hline $\begin{array}{l}\text { Estando viviendo en casa de } \\
\text { mis padres, con la honestidad y } \\
\text { recogimiento propio de mi edad } \\
\text { y sexo, buscó el demandado } \\
\text { oportunidad de comunicarse } \\
\text { conmigo, como lo hizo, siendo } \\
\text { admitido en mi casa con la con- } \\
\text { veniente urbanidad; al poco } \\
\text { tiempo me significó su amor y } \\
\text { luego sus apetitos y como yo } \\
\text { me resistí, la pasión que lo do- } \\
\text { minaba lo llevó a prometerme } \\
\text { casamiento. Vencieron al fin mi } \\
\text { flaqueza sus tenaces insinuacio- } \\
\text { nes y bajo esa promesa usó de } \\
\text { mi cuerpo y continuó haciéndo- } \\
\text { lo hasta que reconociéndome } \\
\text { embarazada me abandonó ver- } \\
\text { gonzosamente (Demanda de } \\
\text { Mercedes en Chile, 1806; en } \\
\text { Goicovic } 1998: 70 \text { ) }\end{array}$ & $\begin{array}{l}\text { Persuadiéndome con raçones } \\
\text { engañosas y dándome palabra y } \\
\text { mano de ser mi marido, el di- } \\
\text { cho, con poco Amor de Dios, } \\
\text { me estrupó y goço, usando mal } \\
\text { de mi todo el tiempo que estu- } \\
\text { ve en su casa, revalidando una } \\
\text { y muchas veces la palabra que } \\
\text { me tiene dada, de que al pre- } \\
\text { sente se sustrae maliciosamen- } \\
\text { te (Demanda de María Domín- } \\
\text { guez, de San Martín de Trebe- } \\
\text { jo, 1668; en Testón Núñez 1985: } \\
\text { 29) }\end{array}$ & $\begin{array}{l}\text { Es cierto se halla preñada de } \\
\text { tres meses de Francisco García } \\
\text { Montañés. El dicho Francisco la } \\
\text { estubo mucho tiempo diciendo } \\
\text { se casaría con la declarante, } \\
\text { debajo de cuya palabra la con- } \\
\text { siguió y la hubo doncella por el } \\
\text { principio del mes de mayo de } \\
\text { este año, habiendo tenido el } \\
\text { primer acto torpe y carnal en un } \\
\text { sitio que llaman calle de la pi- } \\
\text { mienta (Demanda de Francisca } \\
\text { Portillo, de Almodóvar del Cam- } \\
\text { po, 1705; Archivo Municipal de } \\
\text { Almodóvar del Campo) }\end{array}$ \\
\hline
\end{tabular}

Y densidad también, como decíamos, en la palabra de casamiento como motivo literario, especialmente en el teatro del siglo de oro. Una revisión de éste, aún sin ser exhaustiva, refleja el lugar central que ocupa en al menos las siguientes obras: de Tirso de Molina, La villana de Vallecas, El vergonzoso en palacio, El árbol del mejor fruto, Cómo han de ser los amigos, El burlador de Sevilla, El bonroso atrevimiento, La santa Juana, Don Gil de las calzas verdes y Ventura te de Dios, hijo; de Juan Ruiz de Alarcón, La cueva de Salamanca, El desdichado en el fingir, Ganar amigos y la amistad castigada; de Guillén de Castro y Bellvís, El Narciso en su opinión; de Ana Caro de Mallén, Valor, agravio y mujer y El conde Partinuplés; de Lope de Vega, Amor, pleito y desafio; de Antonio Mira de Amescua, Cuatro milagros de amor, Nardo Antonio Bandolero, No bay reinar como vivir y No bay burlas con las mujeres; de Calderón de la Barca, Con quien vengo, vengo; de María de Zayas, La traición de la amistad y de Sor Juana Inés de la Cruz, Los empeños de una casa ${ }^{2}$. En la siguiente

\footnotetext{
${ }^{2}$ La revisión de estas obras se ha realizado con las versiones a texto completo disponibles en http://www.cervantesvirtual.com y, sobre todo, en la impresionante colección de la Association For Hispanic Classical Theater, Inc., casi 250 títulos en http://www.trinity.edu/org/comedia/
} 
selección se puede apreciar la diversidad de contextos en los que aparece el señuelo de la palabra de casamiento asociada a las retóricas literarias del engaño amoroso.

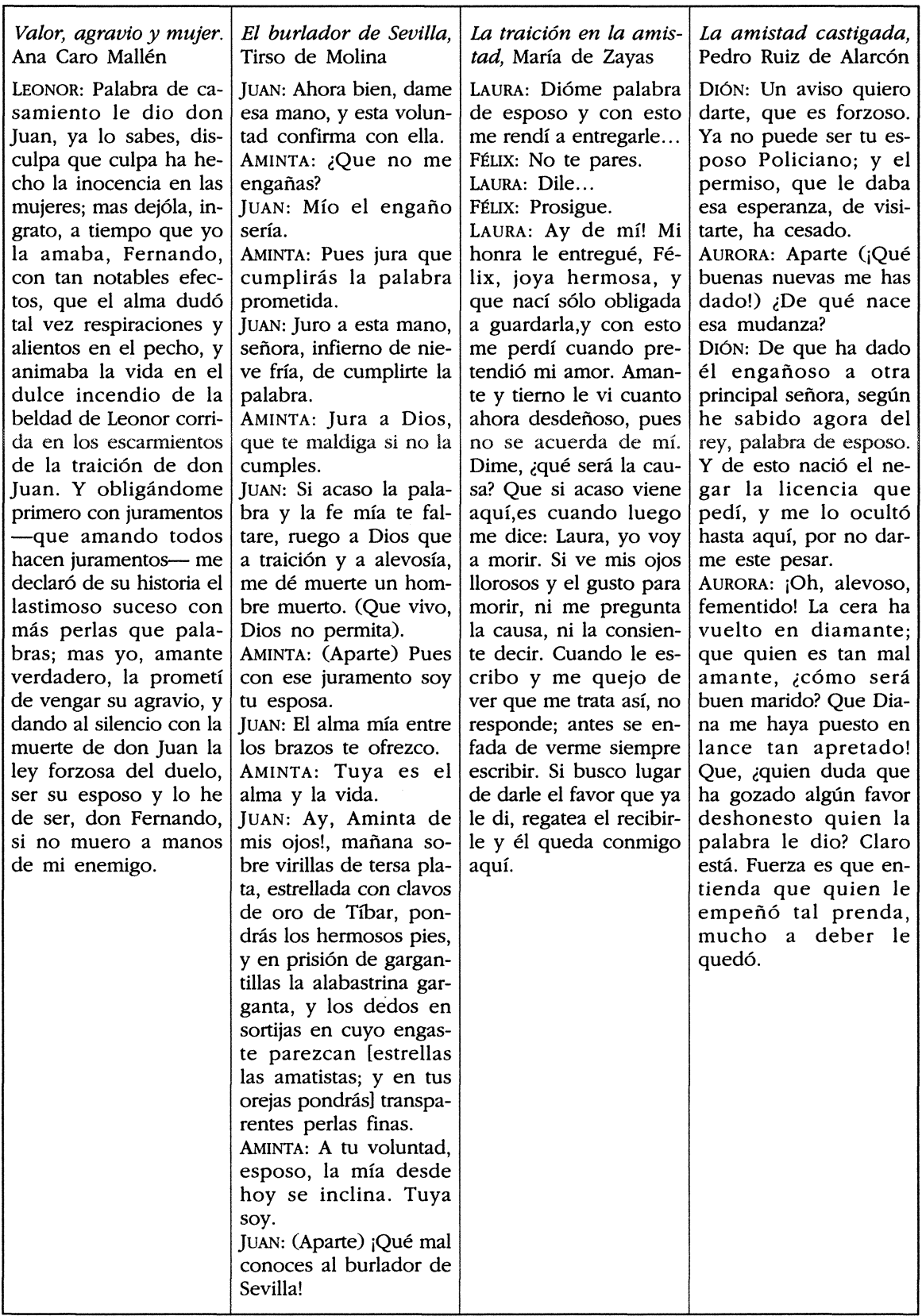




\begin{tabular}{|c|c|c|c|}
\hline $\begin{array}{l}\text { La villana de Vallecas, } \\
\text { Tirso de Molina } \\
\text { PEDro: Palabra de es- } \\
\text { poso dió a cierta doña } \\
\text { Violante en Valencia, y } \\
\text { al instante se fué que la } \\
\text { deshonró. El árbol del } \\
\text { mejor fruto. } \\
\text { Persuasiones amorosas } \\
\text { derribaron la muralla } \\
\text { de mi noble resistencia; } \\
\text { dísteme mano y pala- } \\
\text { bra de esposo, y en } \\
\text { pago de ella te di yo } \\
\text { dentro del alma el ab- } \\
\text { soluto dominio que } \\
\text { funda su imperio en } \\
\text { llamas. Un hijo, que es } \\
\text { el que ves, hizo nudo } \\
\text { las lazadas de mi amor } \\
\text { y tu firmeza; mas como } \\
\text { el tiempo desata obli- } \\
\text { gaciones de bronce, } \\
\text { milagros de su mudan- } \\
\text { za pervirtieron tu me- } \\
\text { moria, dieron principio } \\
\text { a mis ansias. }\end{array}$ & $\begin{array}{l}\text { La cueva de Salamanca, } \\
\text { Juan Ruiz de Alarcón. } \\
\text { ¿Quién vio la amorosa } \\
\text { yedra a un muro de } \\
\text { nieve asir, o por árbol } \\
\text { de diamante trepar la } \\
\text { halagüeña vid? Su ho- } \\
\text { nor opone a mi ruego, } \\
\text { a mi fuerza el resistir, a } \\
\text { mi terneza un demo- } \\
\text { nio, a mi enojo un se- } \\
\text { rafín. No sé qué haga } \\
\text { perdido; medios prue- } \\
\text { bo más de mil; doyle } \\
\text { palabra de esposo, juro } \\
\text { que la he de cumplir... } \\
\text { ¿Quién pensara que } \\
\text { mujer que jura morir } \\
\text { por mi, en tal ocasión, } \\
\text { con esto no diera a mis } \\
\text { ansias fin? «No precio } \\
\text { palabras*, dijo, "que } \\
\text { nunca, don Diego, vi al } \\
\text { que deseoso ofrece, } \\
\text { arrepentido cumplir. Si } \\
\text { ser mí esposo pensaras, } \\
\text { no hubieras venido así, } \\
\text { que no busca malos } \\
\text { medios el que camina a } \\
\text { buen fin. Sí has de ca- } \\
\text { sarte, no quieras que } \\
\text { haya yo sido rüin; y si } \\
\text { me engañas, no quiero } \\
\text { quedar sin honra y sin } \\
\text { ti. Y para acabar por- } \\
\text { fías, yo me determino } \\
\text { aquí, a no cumplir tu } \\
\text { deseo, o entre tus ma- } \\
\text { nos morir.» }\end{array}$ & $\begin{array}{l}\text { El Médico de su bonra, } \\
\text { Calderón De la Barca } \\
\text { LEONor: ¿Con qué razo- } \\
\text { nes, gran señor, herida } \\
\text { la voz, diré que a tan- } \\
\text { to amor postrada, aun- } \\
\text { que el desdén me pu- } \\
\text { blicó ofendida, la vo- } \\
\text { luntad me confesó } \\
\text { obligada? De obligada } \\
\text { pasé a agradecida, lue- } \\
\text { go de agradecida a } \\
\text { apasionada; que en la } \\
\text { universidad de enamo- } \\
\text { rados, dignidades de } \\
\text { amor se dan por gra- } \\
\text { dos. Poca centella inci- } \\
\text { ta mucho fuego, poco } \\
\text { viento movió mucha } \\
\text { tormenta, poca nube al } \\
\text { principio arroja luego } \\
\text { mucho diluvio, poca } \\
\text { luz alienta mucho rayo } \\
\text { después, poco amor } \\
\text { ciego descubre mucho } \\
\text { engaño; y así intenta, } \\
\text { siendo centella, viento, } \\
\text { nube, ensayo, ser tor- } \\
\text { menta, diluvio, incen- } \\
\text { dio y rayo. Dióme pa- } \\
\text { labra que sería mi es- } \\
\text { poso; que éste de las } \\
\text { mujeres es el cebo con } \\
\text { que engaña el honor el } \\
\text { cauteloso pescador, } \\
\text { cuya pasta es el Erebo } \\
\text { que aduerme los senti- } \\
\text { dos temeroso. El labio } \\
\text { aquí fallece, y no me } \\
\text { atrevo a decir que min- } \\
\text { tió. No es maravilla. } \\
\text { ¿Qué palabra se dio } \\
\text { para cumplilla? Con } \\
\text { esta libertad entró en } \\
\text { mi casa, si bien siem- } \\
\text { pre el honor fue reser- } \\
\text { vado; porque yo, libe- } \\
\text { ral de amor, y escasa } \\
\text { de honor, me atuve } \\
\text { siempre a este sagrado. } \\
\text { Mas la publicidad a } \\
\text { tanto pasa, y tanto esta } \\
\text { opinión se ha dilatado, } \\
\text { que en secreto quisie- } \\
\text { ra más perdella, que } \\
\text { con público escándalo } \\
\text { tenella.» }\end{array}$ & $\begin{array}{l}\text { Nardo Antonio Bando- } \\
\text { lero, Antonio Mira de } \\
\text { Mescua } \\
\text { ALDONZA: ¿Soy yo tien- } \\
\text { da de barbero que de } \\
\text { enigmas se compone? } \\
\text { La verdad deciros quie- } \\
\text { ro. Sabed que a una } \\
\text { zarzamora picó este } \\
\text { tordo en mi pueblo } \\
\text { dándola antes de picar- } \\
\text { la palabra de casamien- } \\
\text { to. Si empalagado pro- } \\
\text { cura con promesas y } \\
\text { embelecos picar en } \\
\text { vos, joje allá! zarzamo- } \\
\text { ra, tened seso, que tien } \\
\text { ya este tordo torda y os } \\
\text { quiere burlar aquesto. } \\
\text { Basta, y já las zarzamo- } \\
\text { ras! } \\
\text { INÉs: Escucha. } \\
\text { ALDONZA: Quieren po- } \\
\text { leo? } \\
\text { Vase } \\
\text { INÉs: ¡Oh engañoso don } \\
\text { Luis! De tu natural tra- } \\
\text { vieso y mudable condi- } \\
\text { ción no te esperaba } \\
\text { sino esto. Aunque tan- } \\
\text { to te he querido no vie- } \\
\text { ne tarde el remedio; a } \\
\text { César dejé por ti, des- } \\
\text { de hoy por César te } \\
\text { dejo. Hoy daré satisfac- } \\
\text { ción a mi venganza y } \\
\text { sus celos y a mi mu- } \\
\text { danza disculpa. iAy } \\
\text { hombres, plumas al } \\
\text { viento! }\end{array}$ \\
\hline
\end{tabular}


Tras de la doble lectura de demandas reales y pleitos de ficción no sería razonable pensar en causaciones unívocas. Tenemos el motivo literario del hombre que engaña bajo palabra de casamiento y persuasión seductora, y tenemos paralelamente el motivo literario de la mujer que se deja engañar y es seducida por esa palabra de casamiento pero también por la "flaqueza" o la "fragilidad" propias de la condición femenina. Un siglo separa la saturación de este tema en obras de teatro (s. XVIII) y en archivos judiciales (s. XVIII), tiempo más que suficiente para que las mujeres de todos los rincones de España conociesen el final feliz que para ellas tenía el pleito teatral. La esperanza de conseguir, si no un final tan dichoso, por lo menos cierta comprensión social y cierto retraimiento de la crítica las pudo llevar a apropiarse de argumentos y esquemas narrativos de las obras teatrales.

AMOR DENSO: ÑOÑERÍA, GUIÑOS ATREVIDOS Y RETÓRICAS POPULARES

\begin{tabular}{|c|c|c|}
\hline 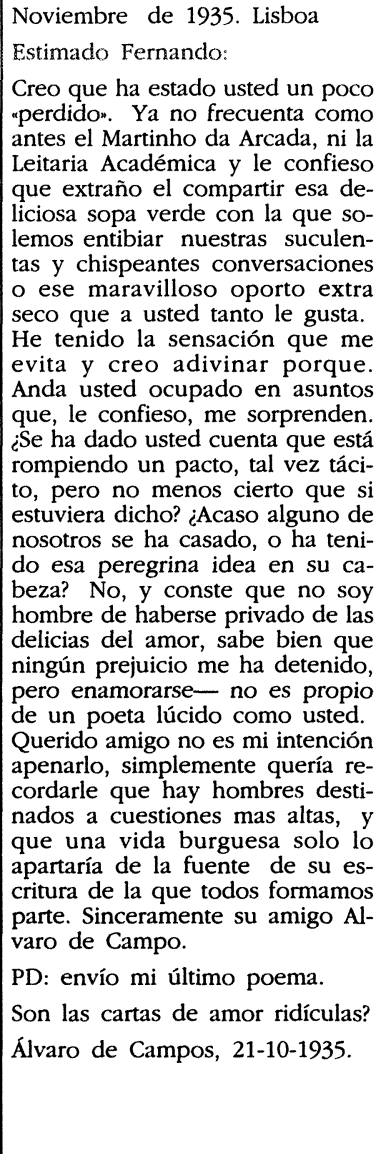 & $\begin{array}{l}\text { Noviembre de } 1935 \text {. Lisboa } \\
\text { Estimado amigo: } \\
\text { Con qué infinita crueldad ha es- } \\
\text { crito usted el poema que me ad- } \\
\text { junta. Y, sin embargo no puedo } \\
\text { menos que reconocer que me } \\
\text { pone frente a una verdad que he } \\
\text { tratado de desestimar. Así he in- } \\
\text { currido en un tardío y vergonzo- } \\
\text { so arrebato de esperanza que me } \\
\text { llevó a pensar que yo estaba des- } \\
\text { tinado a aquello que todo hom- } \\
\text { bre anhela en lo mas profundo de } \\
\text { su corazón, ser amado por una } \\
\text { mujer, tener un hogar, hijos tal } \\
\text { vez que lo conforten en la vejez. } \\
\text { Usted ha venido a confrontarme } \\
\text { con la realidad de un destino } \\
\text { signado por el desasosiego, la } \\
\text { soledad, y el desesperado oficio } \\
\text { de construirme un mundo con pa- } \\
\text { labras. Ojalá yo tuviese ese modo } \\
\text { cínico. }\end{array}$ & $\begin{array}{l}\text { Noviembre de } 1935 . \\
\text { Lisboa Mi querida Ophelia: } \\
\text { He meditado largamente la forma } \\
\text { en que debía acometer la delica- } \\
\text { dísima misión de escribir una nota } \\
\text { en extremo comprometida con el } \\
\text { futuro de todos nosotros. En efec- } \\
\text { to: aquellas largas disputas verba- } \\
\text { les con Fernando me han acerca- } \\
\text { do sus concepciones, ambiguas, } \\
\text { inasibles, multifacéticas. Nada sen- } \\
\text { cillo ha sido imaginarlo como una } \\
\text { integridad pensante, sino indagan- } \\
\text { do ciertas sutiles hiladuras en el } \\
\text { torrente de sus tramas. Esta in- } \\
\text { quietud se ha poblado de noches } \\
\text { de insomnio, abundante bebida y, } \\
\text { quizás, hasta de una incipiente } \\
\text { saciedad literaria, después de tra- } \\
\text { jinar la palabra durante horas y } \\
\text { más horas. Mi postura, en todos } \\
\text { los casos, fue coherente, uni- } \\
\text { tariamente sólida y observadora, } \\
\text { pero su diversidad creadora me } \\
\text { superaba, huía de mí. Entonces } \\
\text { descubrí ciertas esencias y allí es- } \\
\text { tuvo la clave. Con gran cuidado, } \\
\text { meditando cada tramo, diría que } \\
\text { hasta cada palabra, coma o signo, } \\
\text { le escribí una carta y un poema. } \\
\text { Reaccionó rápidamente: me res- } \\
\text { pondió por carta solicitándome } \\
\text { que te escriba para pedirte que lo } \\
\text { excuses de su amor por ti. iEl vie-- } \\
\text { jo tonto cayó en la trampa al fin! } \\
\text { Nos ha dejado el camino expedi- } \\
\text { to, Ophelia, mi amor. Tanto des- } \\
\text { velo al cabo dio sus frutos. Me } \\
\text { siento, orgullosamente (salvando } \\
\text { las distancias), como el -Maestro- } \\
\text { de la inolvidable novela de Henry } \\
\text { James. ¿Qué opinas acerca de un } \\
\text { viaje juntos a París para un feste- } \\
\text { jo a pasionado? Tuyo siempre } \\
\text { Álvaro }\end{array}$ \\
\hline
\end{tabular}


Quizá no todas las cartas de amor sean ridículas y, desde luego, el concepto de ridículo varía según el contexto. Pero bien podría haber servido a Pessoa de sugerencia la relación amorosa que ahora presento para ese conocido poema sobre las cartas de amor ridículas. Se trata de un pedazo de la paroxística relación epistolar entre Miguel Ripoll (también Miguelillo, Lillo, Lillito, Migulchu y otros adjetivos) y Sebastiana Balaguer (también Sebas, Sebastianilla, Tianilla y otros muchos adjetivos) ${ }^{3}$. Un pedazo, pues abarca sólo un año de la relación (del verano de 1902 al verano de 1903), integra sólo algunas de las postales que se enviaron ese año; postales que son sólo una parte del diálogo epistolar intensísimo que también incluía cartas, en alguna ocasión telegramas e incluso, a veces, llamadas telefónicas. Son, no obstante 61 tarjetas postales que nos permiten entrar en las retóricas del amor como pocas veces se puede (ver anexo 2). Conocemos muchos aspectos de la vida privada a través de algunos estudios hechos a partir de cartas, pero no sobre sentimientos íntimos de personas anónimas. En Francia, el análisis realizado de más de 11.000 cartas dirigidas a Marie y Eugène Boileau entre 1873 y 1920 da informaciones "acerca de los hijos, los negocios, las visitas e intercambios familiares, y sobre todo, la salud. Pero apenas si dejan traslucir sentimientos íntimos. La correspondencia tiene un función ritual: señala en concreto la existencia de los vínculos afectivos y su valor no radica tanto en lo que dice como en la regularidad de su funcionamiento" (MartinFurgier 1989: 203) O, como dice Alain Corbin, que también ha considerado el estudio de las cartas en el análisis de la vida privada, éstas pueden hablar de taras familiares, de problemas económicos o de salud, pero "Son avaras en confidencias y confesiones personales" (Corbin 1989: 523). Así, aunque "La configuración del sentimiento amoroso y las conductas que inspira revelan a la vez los sueños eróticos y las tensiones que atraviesan la sociedad [...] La historia contemporánea ha olvidado, sin embargo, este aspecto de las mentalidades. Aficionada a las series, ha preferido el estudio cuantitativo de los embarazos prenupciales al de las correspondencias íntimas" (Ibid.: 524).

Lucienne Frappier-Mazur presenta alguna sugerencia muy interesante respecto a la entrada en escena del amor romántico, a principios del siglo xIx y para una pequeña porción social. Primero, el amor romántico como sustituto de la emoción religiosa es afín a la confesión y susceptible de recompensa:

\footnotetext{
${ }^{3}$ Las postales fueron adquiridas en una librería de viejo en Madrid, en 1999. Forman parte de la colección que vengo conformando para un estudio sobre la expresión gráfica del amor en el s. xx.
} 
El amor será un segundo cielo, la afinidad vivida en la común aventura espiritual. Entre los procedimientos de la confesión y la dialéctica amorosa se entreteje un estrecho vínculo, como si, según advierte, lo reprimido siguiera para su retorno, las sendas asociativas utilizadas durante la represión. La experiencia romántica del amor toma en préstamo del sacramento el lenguaje religioso de la confesión, la función redentora del sufrimiento, la espera de la recompensa. Aquí es la mujer quien conserva el magisterio espiritual; es ella la que justifica las opciones. Pero el amor romántico encierra una complejidad mucho mayor; el lenguaje religioso se combina con el nuevo estatuto de la pasión... La pasión no va a ser en adelante más que una energía; es la que provoca ese choque eléctrico del ser preludio del amor. Este último, lazo entre dos individuos a la vez que penetración común en el seno de una esfera mágica, asegura el tránsito del orden natural al orden poético (Frappier-Mazur 1989: 528).

En segundo lugar, está la diferencia de género respecto al amor; la mujer más vinculada a la idea anterior, el hombre intentando contravenir el código angelical como heredero de tópicos literarios de la conquista (miradas, sonrisas, roces...):

La manifestación del deseo masculino contraviene totalmente el código angélico; ése es el origen del refinado erotismo del sistema. A la palabra que resultaría demasiado escandalosa, la suple durante mucho tiempo la mirada, la sonrisa y en un caso extremo el roce, la turbación, el rubor, el silencio insistente son otras tantas respuestas... Todo esto forma parte del proceso de la educación sentimental que es un tópico de esta literatura (Ibid.).

Y, en tercer lugar, el análisis de cómo se produce la expansión desde las clases altas a las populares:

Sería de enorme importancia analizar el proceso de descenso del amor romántico hacia la base de la pirámide social. La iglesia sugiere a los comulgantes ensueños angélicos. La influencia de la canción y de una literatura barata... el éxito del melodrama donde Margot llora, las novelas en préstamo que se leen en la cocina, y luego los folletines, constituyen otros tantos canales a través de los cuales circula el nuevo mundo imaginario sentimental... A los enamorados que buscan un modelo, la tarjeta postal va a proponerles a partir de 1890, un sistema prefabricado de actitudes, una escenificación del sentimiento, y los emblemas del día de San Valentín. La tarjeta postal va a democratizar la declaración amorosa (Ibid.).

El ejemplo que presento muestra la complejidad del problema, primero porque no parecen tan claras las diferencias de género $\mathrm{y}$, segundo, porque no resulta pertinente ver sólo cómo el amor romántico desciende a las clases populares, sino también cómo de éstas el amor asciende hacia aquellas que usan sus retóricas como un aderezo necesario, aunque con incompetencia en muchos casos. No se trata sólo de una relación dentro de la burguesía, tomada de una educación sentimental "alta" que modeliza la literatura y que puede "descender" a través de canciones, folletines y 
literatura barata; tampoco de tarjetas postales que descienden para guiar comportamientos amorosos del pueblo; entre otras cosas porque las tarjetas postales en esta época no son, ni mucho menos, bienes democráticos, sino marcadores de clase alta. Estamos en presencia de una batería de recursos variadísimos para expresar el amor: uso de la imagen como excusa para un mensaje, que no siempre se ajusta a la esperable corrección de clase, uso de recursos literarios de toda índole, de literatura culta —de culto", podríamos decir-, literatura también elitista pero ligera y junto a eso, además literatura y canciones populares. Una compleja expresión del amor para un pareja típicamente romántica, aunque ellos fuesen atípicos.

Efectivamente, Sebastiana y Miguel son una pareja atípica: de la minoría que representa la clase alta, de una minoría igualmente ilustrada -aún dentro del marco de su clase social-, conocedores de la retórica amorosa noña ${ }^{4}$, pero también avanzados para su tiempo y su clase, como se aprecia en los guiños atrevidos y los recursos literarios populares que dan chispa a la relación y que dan a entender que el amor romántico tiene muchas aristas. Su adscripción local es también atípica: viven en Madrid, en el centro de Madrid, él parece que en el domicilio familiar y ella en la casa de otros familiares, pues su núcleo familiar está en San Sebastián, de donde procede, a donde va de vacaciones y a cuyo santo patrón debe su nombre. Por otro lado, sus apellidos, Ripoll y Balaguer, denotan claramente una procedencia catalana. Además son primos. Cabe suponer que se trata de una estirpe militar a cuya continuidad se presta Miguel que en 1901 ingresa en la Academia Militar de Guadalajara para especializarse en ingeniería, así Miguel Ripoll será también para Sebastiana, "el ingeniero" o "mon ingeniéur".

Los marcadores de clase son claros, como lo denota el mismo hecho de la continua y constante relación epistolar y el reiterado envío de postales - casi diario-, recurso no al alcance de todos. No está claro a qué se dedica formalmente Sebastiana en Madrid, aunque sí sabemos que toca el piano - pero se aburre-, la visita frecuentemente la peinadora en casa, borda, sale de paseo, mira por el balcón, toma chocolate, habla francés, parece que también puede leer en "vascuence", pasa muchas horas en el balcón de su casa madrileña en Jacometrezo; se levanta tarde, por lo que no puede ir muchas veces a misa, acto religioso que trata con desdén, y,

\footnotetext{
${ }^{4}$ Práctica al parecer común: "En la intimidad, la familia burguesa se tutea y se dan de buena gana diminutivos afectuosos, ridículos a las vez que sorprendentes. César Birotteau llama a su mujer 'Mimí', 'mi blanca nena bonita', 'mi gatita querida'n (en Corbin 1998: 254).
} 
sobre todo, escribe, escribe sin parar con una cuidadísima y pulcra caligrafía, en varias tintas, cambiando mayúsculas y minúsculas, componiendo obras de arte en cada postal. La última carta del repertorio que conozco muestra la insufrible cotidianeidad de tiempo muerto que supone, para ella, la ausencia del amado: después de despedirlo en la estación de Atocha y regresar de vuelta paseando por el paseo del Prado y la calle de Alcalá, "Para las 8,10 estaba ya descuidada y he estado un Ratito con Roque en el balcón a las 8,30 he tomado el chocolate y he cosido un poco, a las 9 ha venido la chica, la he dicho lo que tenía que hacer y me he peinado y después entre coser un poco y dar unas vueltas por las habitaciones se me ha pasado la mañanam. Por su parte, la vida de Miguel en Guadalajara está mediatizada por sus clases en la Academia y, sobre todo, por los exámenes, que son narrados épicamente (dolorosos no tanto por ellos mismos, sino porque, como dice en la tarjeta 36: "Mucho me incomodaría que me suspendiesen pero sobre todo porque entonces no me dejarían ir hasta el 15") y transmitidos como los momentos más duros de la separación. Fuera de ellos, pasea, juega al tute y al "footballn, va al casino a leer los periódicos, toma también chocolate, acude vestido de gala y con desgana a procesiones, se echa la siesta y recibe al peluquero que a diario lo afeita, se preocupa por su estética corporal (tarjeta n.. 47: "esta mañana al irme a peinar me he visto sorprendido con un grano descomunal en la punta de la nariz iyo que soy tan guapísimo!n) y por la pulcritud de su ropa. Por ejemplo, la carta de 7 de marzo de 1903 (la n. . 58) apunta esa cotidianeidad: "Chiquilla mía, antes que nada te voy a decir lo que he hecho hoy. Después de almorzar hemos estado de charla, ha venido el peluquero y me ha afeitado. A eso de las 4 he dado un paseíto, he llegado hasta donde solemos jugar al foot-ball, me han animado para que jugara, he hecho un tanto derribando al portero y a un arquero, en fin que he pasado un ratito regular, porque tengo que confesarlo soy muy burro y me gustan esos juegos. Después al casino a leer los periódicos, un par de vueltas por la calle mayor, recoger la carta y a casita a leerla.. Y sobre todo también se dedica a escribir, escribir hasta el paroxismo, hasta el punto de que tanto a él como a ella la llegada de una tarjeta postal los encuentra escribiendo. La correspondencia habla de un tiempo muerto, un paréntesis de noviazgo especialmente duro, como es el noviazgo que empieza con el inicio de la formación en la Academia, y que terminará, presumiblemente, cuatro años después cuando el final de la carrera suponga el comienzo de la vida marital. Como dice Sebastiana en la tarjeta n. 13 , "el 7 y 8 [de octubre de 1902] hablaremos muy formal de nuestro matrimonio pues mal que te pese cada día que pasa caminamos un pasito hacia ese feliz día. Cuándo 
diremos falta un día. En fin todo llegará y estaremos muy contentos. No quiero decirte lo felices que seremos. Ya verás cómo nos reiremos pensando lo muchísimo que sufrimos ahora. Nada, hay que animarsen. Y eso es: un año de inspiraciones múltiples en la expresión de su amor, animándose de mil y una formas.

La relación comenzó el 2 de junio de 1901 tal como refiere Sebastiana en su carta de dos años después: "Hoy hace Miguel mío dos años justamente que me hablaste por primera vez; nunca se me olvida el momento aquel en que muy suavemente me cogiste por la cintura y yo estaba así como quien ve visiones bien mío. Y ya pronto cumpliremos los dos años de relaciones. A ver si al cumplir los cuatro terminas la carrera y entonces sí que estaremos muy contentos porque entonces al menos no estaremos separados". En realidad, el inicio formal de relaciones fue algo después, concretamente el 11 de julio de 1901, como se sugiere en la fecha escrita en el libro de la décima postal. Podemos decir que el año que conocemos de relaciones es un tiempo de saturación de la presencia del otro aunque esté ausente. Ya he comentado la cantidad de misivas que se giran, pero no es sólo cuestión de cantidad sino también de calidad. Se trata de hacer ver que uno piensa en el otro, no sólo por lo que se dice, sino por la forma de hacerlo visible. Una forma que exige tiempo y dedicación; como he comentado en otro lugar: "escribir con letra gótica, hacerlo aprovechando resquicios inverosímiles de las postales, escribir con letra lo más diminuta posible y redactar en forma de cuadrícula, horizontal y verticalmente en el mismo espacio, eran algunas de las estrategias utilizadas: el novio gastaba tiempo en la redacción y la novia debía dedicar igualmente tiempo para desentrañar su significado, o a la inversan (López 2003: 127). Todo ello lo vemos en estas postales y aún alguna estrategia más: escribir con distintas tintas, combinando mayúsculas y minúsculas, hablando con boca del otro, de una supuesta hija/o que les habla desde el futuro o dialogando con los personajes de las postales. $\mathrm{O}$, en fin, hacer que la lectura de la propia postal se convierta en un juego, un laberinto en que hay que ir buscando la continuidad del texto, así sucede por ejemplo con la postal n.․ 47. Veamos. La misiva comienza en el lado estrecho de la izquierda de la postal con dos líneas: "Querida Sebastiana no puedes figurarte lo largos que se me hacen los [continúa en la parte inferior derecha] minutos que faltan para que llegue tu carta. Ya han dado las 10 y todavía no ha ve- [parte superior izquierda] nido el cartero. Cada día te quiero más vidita mía, puedes creerte pero te lo digo en serio, que si en los tres años que me faltan [continua en el lado estrecho de la derecha, a lo largo de nueve líneas] para terminar la carrera, nuestro cariño aumenta como hasta ahora, me parece que 
no la termino, pues me será completamente imposible estar separado de mi ingrata cerdita. Esta mañana al irme a peinar me he visto sorprendido con un grano [parte inferior central] descomunal que me ha salido en la punta de la nariz iyo que soy tan guapísimo! Si vieras lo feo que está tu chatillo! [parte superior, derecha]: ¿y sus señorías han regresado ya con carta? Supongo les habrás encargado una visita. Tu pareces a la coneja que está sentada. Qué gordita está ¿verdad fea? Bueno te dejo pues ya no tardará el cartero Rica mía [hacia la parte izquierda, lado estrecho, la despedida] Adios Sebastianilla, te quiere Miguel [en una de las cajas que lleva el conejo] Asquerosita fea [en la otra, la fecha] 16/8/02. Como esta hay varias, por ejemplo la postal n.. 58 .

El contenido impreso de la postal desempeña un papel de apoyatura para enviar mensajes que hablan de la similitud o diferencia con lo que ellos mismos hacen. Se podría hablar de una técnica de desplazamiento: aquellos de la postal son como nosotros, aunque la exégesis que puedan hacer de la postal vaya por otro camino. En la tarjeta n..$^{1}$, el joven que aparece le coge una mano a la muchacha y le pasa el brazo por la cadera: "Mira qué confianza se va tomando el niño este, no se parece a tí verdad hermoso mío?" [lectura del desplazamiento, con retórica de la inversión incluída: "así eres tú de atrevido"]; dos días después el 19 de agosto envía otra con los mismos jóvenes protagonistas, ahora ella sentada en sus rodillas y él pasándole el brazo por la cintura: "Miguel mío, te acuerdas cuando solemos estar así nosotros iqué bien, si vieras qué envidia me da!n; la última tarjeta de la serie que envía es la más atrevida: la pareja cogida de la mano, él abrazándola por la cintura y pegando sus bocas en un beso: "Esta es la última tarjeta, después de esto figúrate lo que iba a venir". Desde luego, después de abrazarse, sentarse en las rodillas, besarse, lo que vendría es una relación sexual. En ese sentido, es realmente sorprendente que hablen de un tipo de relación física de pareja, que aludan incluso implícitamente a relaciones sexuales, llamativo en una lectura aproblemática por la época, por la clase social y, sobre todo, por la notoria cursilería con que están trufadadas las postales; tanto, que parecería no dar cabida al amor físico. Igual expresión, aunque atemperada la libido, se aprecia en al tarjeta $\mathrm{n} . .^{\circ} 10$ en la que dos niños se abrazan y se besan detrás de un abanico: "Amor mío gitanillo de mi corazón: esta es la última tarjeta. Estos terminan como nosotros ¿verdad riquito de mi alma? Mira que tempranito han empezado. Mira qué ojillos más granujas tienen. Mira con qué ganas le agarra él como tu a mi. ¿Cuándo nos veremos así, precioso mío?. Y también en la n.․ 13, en la que una niña está señalando a un niño: "Mira qué guasona es esta nenilla, precioso mío, se parece a mi nene que es también mucho, pero no es malo como esta 
gitanilla [lectura desplazada y con inversión: "mi nene es malo como esta gitanillan. Verdaderamente es mala pues mira cómo le insulta al niñito diciéndole "esta no es para tu estrafalaria nariz" Cuidado que es mala. Yo soy muy buena, yo no te hago rabiar y de esa manera te evito la molestia de que me levantes las faldas y me des azotes [lectura: “yo soy mala, sí te hago rabiar... te invito a que me des azotes"] ¡vaya yo no quiero eso se hace cuando una es pequeña pero yo soy ya muy formal para que me hagas eso. Cuando estamos juntos hablamos muy poco y es que besándonos nos entusiasmamos tanto que no sabemos qué decirnos". El asunto de los azotes viene a cuento por otra postal del día 10 de septiembre que él le envía (n.․ 53), en la que aparecen dos niños con juguetes, él jugando con un caballito y ella con la mano levantada, como amenazando: "Mírala qué rabiosa se ha puesto imenuda paliza le va a pegar el chiquillo, vaya unos azotitos que se va a ganar en el culito! Y eso por cochina. Yo voy a hacer lo mismo cuando me hagas incomodar, no te olvides que te he prometido unos cuantos. Te quiero con locura tu hermosísimo Miguel. Igualmente podemos decir de la carta 33 en la que aparece una chica en camisón de dormir frente a una ducha: "Cuando estoy con la camisa de noche me parezco a esta nenillo, pero bastante mejor porque como tu nena es muy hermosa la está muy bien"; de la ducha que tiene en frente, en vez de gotas caen frases-manifiesto de amor: "gitanillo encantador de mi corazón", "preciosidad de su nenilla", "eres mi única ilusión", "quién te quiere a ti mucho?». Diferente el camisón de noche al traje de monja; implica vocaciones distintas, como dice en la tarjeta 24: "Oye, verdad que yo no estaría mal de monjita, pero no tengo vocación que es lo que hace falta" Igualmente la n. 40 de Miguel a Sebastiana, a propósito del gato de la serie, le habla del otro gato real, el erizo, que ella tiene: "Al erizo que tienes le voy a domesticar este verano para que cuando seas mala se te suba por las pantorrillas verás qué gusto te da." El interés por las pantorrillas aparece otra vez en la n.․ 55, recurriendo la niña de la postal en el contexto de una ensoñación: "He tomado chocolate y no te he convidado preciosilla mía porque creí que no podrías asistir pero si tu crees lo contrario ven enseguida que te lo haré lueguito, que aún debe tener gusto ¡vie ma riquita mia! Vaya unas pantorrillas más monas tiene la nena..."

Si las retóricas del desplazamiento son guiños atrevidos que invitan a hablar oblicuamente de sensualidad, la postal se conforma también con muchos otros recursos. Está presente el recurso literario culto elitista, también el recurso literario "ligero", que se conecta más claramente con ese tono cursi que parece envolver toda la correspondencia, y está también la literatura popular o metaliteratura —según empleaba Foucault el térmi- 
no- que "asciende". Y tenemos entonces que la tarjeta postal es un collage imposible de interpretar sólo etnolitariamente, aunque la literatura tenga mucha importancia.

Sabemos por la literatura que la propia literatura es fuente de inspiración epistolar. Mariano José de Larra informa en Casarse pronto y mal que La Nueva Eloísa de Rousseau servía más que de inspiración a amantes de la burguesía ya bien entrado el siglo XIX, así por ejemplo refiriéndose a su propio sobrino quien:

Por su desgracia acertó a gustar a una joven, personita muy bien educada también, la cual es verdad que no sabía gobernar una casa, pero se embaulaba en el cuerpo en sus ratos perdidos, que eran para ella todos los días, una novela sentimental, con la más desatinada afición que en el mundo jamás se ha visto; tocaba su poco de piano y cantaba su poco de aria de vez en cuando, porque tenía una bonita voz de contralto. Hubo guiños y apretones desesperados de pies y manos, y varias epístolas recíprocamente copiadas de la Nueva Eloísa.

Podemos sí apreciar aquí la influencia de la Julia de Rousseau, pero también la inspiración de la correspondencia entre Flaubert y Colet cuando sube un poco el tono de la pasión y, sobre todo, en el impulso irrefrenable de escribir y el ansia indescriptible de recibir carta, hasta el punto que, tanto en las de Miguel a Sebastiana, como en las de Flaubert a Colet, el cartero se convierte en un personaje familiar querido y odiado según traiga carta o no; según llegue a tiempo o se retrase ("J'ai attendu ce matin le facteur une grande beure sur le quai. Il était aujourd'bui en retard. Que cet imbécile-là, avec son collet rouge, a sans le savoir fait battre de coeurs!n, carta IV de Flaubert). Pero no sólo hay inspiración en la literatura epistolar, el amor romántico se construye con toda clase de literatura romántica sea esta más ligera, como la de Menéndez Valdés (“Sabes, oh palomita, / sabes, di, lo que envidio? / Ea, pues, si lo aciertas / tienes un beso mío"), reconocible en toda la correspondencia o sea más "culta", como la referida de Flaubert. Si tuviésemos que referirnos a "Figuras" al estilo de Roland Barthes (1997) una primera y principal sería la ñoñez, pero otra la pasión, hasta el punto de que podemos hablar de los amores volcánicos de Sebastiana y Miguel (del modo, por ejemplo, a como lo hace Galdós en La vuelta al mundo de la Numancia: "más fácilmente se apaga un volcán que el incendio de un corazón enamorado"). Así, en la carta n. 13 dice Sebastiana: "al volcánico ingeniero que abrasa de amor a su nenilla"; o en la 19: "a mi Lillito que me está matando con tanto amor". También tiene esa fuerza pasional el motivo de invitarse mutuamente a comer en la distancia y que aparece de manera recurrente en las tarjetas (n. ${ }^{\circ}$ 13: "Voy a comer igustas hacerlo con tu nenilla: te daré a la boquita, después te daré café y luego echaremos la siesta si es que tú quieres"). 
Pero no es sólo eso, hay motivos que no están en la literatura, por lo menos no están en esa literatura, sino en la metaliteraria, en canciones populares, por ejemplo, y que son vivero, sobre todo, de la extensión de algunos adjetivos que sirven para crear otro motivo amoroso, otra "figura", la del "amor del pueblon. Tomando esta perspectiva, ella es retrechera, gachí y gitanilla; él gitanillo, serranillo, moreno, y también gachó. El motivo de la retrechera "asciende" del pueblo, y por eso puede aparecer, a lo largo de la primer mitad del s. Xx en una bulería de la Niña de los Peines o del Indio Gitano, en un pasodoble del maestro Laredo, en un tango de Eduardo Trongé y Carlos P. Cabral, en una jota de Navalmoral de la Sierra (Ávila) o en una canción de Romería de Linares.

\begin{tabular}{|c|c|c|c|c|}
\hline $\begin{array}{l}\text { PASODOBLE } \\
\text { "Guapa, Guapa, } \\
\text { Guapa" (Maestro } \\
\text { Laredo) }\end{array}$ & $\begin{array}{l}\text { ROMERÍA DE LA } \\
\text { VIRGEN DE } \\
\text { LINARES } \\
\text { "Arroyito de } \\
\text { Linares" } \\
\text { (Ramón Medina) }\end{array}$ & $\begin{array}{l}\text { TANGO } \\
\text { «No tome más abuelo } \\
\text { (Eduardo Trongé y } \\
\text { Carlos P. Cabral }\end{array}$ & $\begin{array}{l}\text { BULERIA } \\
\text { «Por tu forma de } \\
\text { mirar (La Niña de } \\
\text { los Peines) }\end{array}$ & $\begin{array}{l}\text { JOTA POPULAR } \\
\text { DE NAVALMORAL } \\
\text { DE LA SIERRA } \\
\text { (ÁVILA) Estrofa }\end{array}$ \\
\hline $\begin{array}{l}\text { Estás que arreba- } \\
\text { tas preciosa,/ estás } \\
\text { de lo más retre- } \\
\text { chera,/estás tan } \\
\text { bonita y graciosa/ } \\
\text { que luces airosa } \\
\text { tu sal postinera;/ } \\
\text { estás tan soberbia } \\
\text { y airosa/que luces } \\
\text { mimosa tu gracia } \\
\text { chispera. }\end{array}$ & $\begin{array}{l}\text { Nenas de Santa } \\
\text { Marina y de San } \\
\text { Juan de Letrán;/ } \\
\text { nenas de Córdoba } \\
\text { entera,/ con mi } \\
\text { caballo alazán/te } \\
\text { espero en la carre- } \\
\text { tera/ que a la gru- } \\
\text { pa he de llevarte,/ } \\
\text { cordobesa retre- } \\
\text { chera,/ porque } \\
\text { quiero pasearte } \\
\text { aunque tu novio } \\
\text { no quiera. }\end{array}$ & $\begin{array}{l}\text { Si vieras qué crio- } \\
\text { lla de ojos ne- } \\
\text { gros,/ de blanca } \\
\text { tez, risueña y ju- } \\
\text { guetona,/ de lin- } \\
\text { do andar, retre- } \\
\text { chera y comadro- } \\
\text { na,/ clavel de } \\
\text { amor florecido en } \\
\text { mis recuerdos. /Si } \\
\text { vieras vos con } \\
\text { qué ansias la que- } \\
\text { ría,/ con cuánto } \\
\text { a fá n h i ci mos } \\
\text { nuestro nido.../ } \\
\text { Más ella, cruel, } \\
\text { destrozando mi } \\
\text { alma,/un día, con } \\
\text { mi mejor compa- } \\
\text { ñero me engañó. }\end{array}$ & $\begin{array}{l}\text { Mira si te quiero } \\
\text { yo/que por los } \\
\text { ojos me salen/ el } \\
\text { alma y el corazón/ } \\
\text { gitanita, gitanita,/ } \\
\text { gitanita retreche- } \\
\text { ra/ yo tengo una } \\
\text { chabolita/ pa que } \\
\text { duerma tu compa- } \\
\text { ñera/ mira si te } \\
\text { quiero yo/ que } \\
\text { por los ojos me } \\
\text { salen/ el alma y } \\
\text { el corazón/ ay, } \\
\text { mamá que me voy } \\
\text { a casar/ que me } \\
\text { voy a casar con } \\
\text { esta mujer. }\end{array}$ & $\begin{array}{l}\text { Eres una retreche- } \\
\text { ra,/ que cuando } \\
\text { vas a mercar/ } \\
\text { todo te cuesta el } \\
\text { dinero/ y dices } \\
\text { que te lo dan. }\end{array}$ \\
\hline
\end{tabular}

Como un ejercicio sólo ejemplificador incluyo adjetivos, frases y expresiones de esas tres figuras de inspiración literaria o metaliteraria, aun sabiendo que, aunque las presento en forma de tabla, las fronteras no son férreas, tampoco porosas; quizá la imagen que mejor se corresponda sea la de la comunicación de entre líquidos de densidades distintas. 


\begin{tabular}{|c|c|c|}
\hline Amor pasional & Amor ñoño & Amor del pueblo \\
\hline $\begin{array}{l}\text { Idolatrado; Ángel; divina; "Su } \\
\text { ser amado la que le quiere, ama } \\
\text { y adora de corazón"; " } A \text { son } \\
\text { amoureux fiancé, la poupée"; } A \\
\text { son cher Michel sa petite que } \\
\text { l'aime beaucoup"; "la que le } \\
\text { adora con todas las fuerzas de } \\
\text { su corazón"; "Chiquillo adorado, } \\
\text { cuanto te quiero y te amo, tu } \\
\text { eres y serás mi única ilusión, tu } \\
\text { serás el pensamiento de tu } \\
\text { nenilla siempre, que no piensa } \\
\text { más que en su Lillito del alma"; } \\
\text { "Luz de mis ojos"; "me estás } \\
\text { matando con tanto amor"; "a su } \\
\text { adoradísimo, la que le pertene- } \\
\text { ce en cuerpo y alma"; "Tenemos } \\
\text { que darnos besos ¿no te pare- } \\
\text { ce, amor?; "un corazón que } \\
\text { siempre latirá por ti"; "encanta- } \\
\text { dor adoradon; "loca con tanto } \\
\text { amor"; "no puedo vivir sin ti"; "te } \\
\text { quiero con delirio"; "me gustan } \\
\text { tanto tus besos que sin ellos no } \\
\text { puedo pasar"; "mi corazón her- } \\
\text { virá»; "no pudiendo coger los } \\
\text { besitos de tus lindísimos y ar- } \\
\text { dientes besos me conformo con } \\
\text { recogerlos del frío papel"; "por } \\
\text { ti daría hasta la última gota de } \\
\text { sangre" }\end{array}$ & $\begin{array}{l}\text { Remonín; Monín; Monísimo, } \\
\text { Cielito, Pichón, Pichoncito; en- } \\
\text { cantador; Moñoño; "Hermosísi- } \\
\text { mo nene"/nnene precioso"; } \\
\text { Riquito; "Ricura lucerito de mi } \\
\text { vida"; "A su tortolito querido } \\
\text { que mucho le mima y le quie- } \\
\text { re"; "No te quiero, feo más que } \\
\text { feo, qué te habrás creído tú, } \\
\text { asqueroso"; "Chatito adorado"; } \\
\text { "Chatín del alman; Chatunguín; } \\
\text { Feo; Saladísimo; Gracioso; "A } \\
\text { mi maridito del alma que estoy } \\
\text { loquita por el"; Amoroso; "Nena } \\
\text { esbelta"; "Rechonchita"; "Chiqui- } \\
\text { lla adoradan; "qué tonto querer } \\
\text { a un nene tan horrible"; "escul- } \\
\text { tural figuran; "diablillo malo"; } \\
\text { "feísimo gigante"; "reina mían; } \\
\text { "lorito divino" }\end{array}$ & $\begin{array}{l}\text { "Saladísimo gitano"; "queridísimo } \\
\text { serranillo"; moreno; "Rica mía"; } \\
\text { Gachí; Gachó; Granuja; "Mi co- } \\
\text { neja»; "Soy muy burro"; "Tu va- } \\
\text { quita"; "Cerdita mía", "con que } \\
\text { ganas me agarras"; "a falta de } \\
\text { pan buenas son tortas"; "verás } \\
\text { qué gusto te da [el gato] cuan- } \\
\text { do te suba por las pantorrillas"; } \\
\text { "retrechera" }\end{array}$ \\
\hline
\end{tabular}

Llegados a este punto, cabe decir que el uso de figuras populares sirve para presentar otra cara del amor. Si se usan categorías animales, el amor de "la cerdita", "la coneja" o "el burro", es muy diferente al amor "del pichoncito", "el tortolito", "el lorito" o "el monito"; si se ponen en juego tipología sociales, el amor de gitano, de serrano, de moreno, de granuja, de gachí o de retrechera, es muy distinto al amor del nene, el moñoño o el riquito, muy diferente a su vez "del idolatrado", "el ángel" o "el loco"; o, en fin, si el argumento retórico es el cuerpo, un amor de gusto por las pantorrillas y de azotitos en el culo es muy distinto de un amor centrado en la figura esbelta o escultural, la narices chatitas o el grano en ellas que afea, distinto a su vez del amor "de corazón", de latidos, de suspiros, de sangre, de luz en los ojos y de alma. En las fórmulas asociativas funcionan lógicas distintas. Por ejemplo, las tipologías sociales presentan una distinción con tres vértices: en el vértice "popular" aparecerían tipos asociados al lejano, salvaje, nómada, descarado... en otro, el 
vértice "ñoño", el ingenuo, el simple, el niño y en el tercero, "el pasional, tendríamos al loco. En las tipologías corporales la triangulación se establece entre 1.9) partes del cuerpo con connotación sexual (pantorrillas, culo), 2.9) otras vinculadas a la estética (esbeltez, nariz...) y $3 .{ }^{\circ}$ ) relacionada con el interior (el corazón y sus latidos, la luz de los ojos). Por su parte, cuando se recurre a ejemplificar con animales aparece una lógica inversa: los domésticos (burro, coneja, cerda) están asociados al amor popular, frente al amor noño que es representado por el pichón, el tórtolo, el loro y el mono que no son animales domésticos. Aquí es muy probable que estén funcionando lógicas que marcan dos extremos en la escala de la acción sexual: la exagerada, rápida y sonora (que representan burro, conejo y cerdo), frente a la lenta, galante, cariñosa, parca y arrulladora (que se expresan a través del pichón, el tórtolo o el loro). La curiosidad y el deseo de experimentar en el propio cuerpo con la diferencia lleva a dialogar con la diferencia, aunque se trate de diálogos fragmentarios y cuajados de malentendidos.

Quizá esa combinación de salvaje/sexualidad, niño/belleza-ternura y loco/sentimiento-pasión dan una buena definición de amor, siendo las proporciones de cada una en un todo marcadores de posición social. Los cambios de proporciones desde modelos estereotipados (que definen qué es amor romántico-pasional, romántico-noño y popular) hablan de las fórmulas de apropiación. Aquí hemos visto que no es siempre la cultura popular la que se apropia y reacomoda de motivos que descienden de cultura letrada y de las clases dominantes. Como dice Roland Barthes, en medio de la ternura infantil que hay detrás del abrazo que asemeja un retorno a la madre, "lo genital llega indefectiblemente a surgir; corta la sensualidad difusa del abrazo incestuoso; la lógica del deseo se pone en marcha, el querer-asir vuelve, el adulto se sobreimprime al niño. Soy entonces dos sujetos a la vez: quiero la maternidad y la genitalidad. (El enamorado se podría definir como un niño que se tensa: tal era el joven Eros)" (Barthes 1997: 30). 


\section{AMOR Y AVENTURA DESDE LA RED Y LOS ORÍGENES DEL GUIÓN}

\begin{tabular}{|c|c|c|}
\hline $\begin{array}{l}\text { Porque te amo (Enviado por } \\
\text { gladiator (10 09:55) }\end{array}$ & $\begin{array}{l}\text { Enviado por victor }-29 \text { oct } \\
2004,10: 52\end{array}$ & Comentarios en red. \\
\hline $\begin{array}{l}\text { Porque tu me amas y me haces } \\
\text { sentir amada. Porque no puedo } \\
\text { dudar del amor que veo en tu } \\
\text { mirada, en tus gestos, en tus pa- } \\
\text { labras, en tus caricias y en tus } \\
\text { besos. } \\
\text { Porque tu me comprendes, in- } \\
\text { cluso en la locura, en esta locu- } \\
\text { ra que salpica cada dí, en esa } \\
\text { locura que nos mueve y que } \\
\text { mueve a los que me rodean, en } \\
\text { esa locura que algún día será } \\
\text { paz y que, espero, nos compen- } \\
\text { sará por lo que estamos pasan- } \\
\text { do. Porque, pese a mi locura, tu } \\
\text { me amas. Porque sé que, aun- } \\
\text { que de verdad estuviese loca, tu } \\
\text { intentarías sanarme con tu amor, } \\
\text { me querrías a tu lado, me cui- } \\
\text { darías ... lo que nadie sabe .... } \\
\text { es que mi única locura es mi } \\
\text { amor por ti y ésta es una locura } \\
\text { a la que no quiero renunciar... } \\
\text { Porque tu me ayudas en todo, } \\
\text { en todos los aspectos de mi vida, } \\
\text { me ayudas a conocerme, a } \\
\text { aprender a quererme. Me obligas } \\
\text { a pensar que, tal vez, solo tal } \\
\text { vez, pueda ser alguien que vale, } \\
\text { que sabe querer, que puede ayu- } \\
\text { dar. Que quizás, solo quizás, no } \\
\text { soy tan fea, ni tan estúpida, ni } \\
\text { tan torpe o que, por lo menos, } \\
\text { tú me vas a querer igual ... y } \\
\text { también me va a querer cuándo } \\
\text { envejezca, porque no amas a mi } \\
\text { físico, sino a mi corazón y este, } \\
\text { bien cuidado, no envejece, sino } \\
\text { que mejora con los años. } \\
\text { Porque tú eres mi guía, la luz } \\
\text { que me enseña el camino cuan- } \\
\text { do sólo veo tinieblas, la luz que } \\
\text { me dice que esto también pasa- } \\
\text { rá, la luz de mi presente, la luz } \\
\text { de mi futuro y, estoy segura, } \\
\text { también la luz de mi pasado. } \\
\text { Porque tu eres mi apoyo, pero } \\
\text { el apoyo equilibrado, la otra } \\
\text { pata de la mesa y, sé perfecta- } \\
\text { mente, que esto es gracias a ti } \\
\text { por que, en estos momentos, } \\
\text { eres tu quién sostiene todo el } \\
\text { peso de la mesa, pero tu bon- } \\
\text { dad te impide decírmelo y te } \\
\text { empeñas en ocultarlo para que } \\
\text { yo no desespere. Gracias amor } \\
\text { por dejarme sentir que yo tam- } \\
\text { bién aguanto esta mesa... }\end{array}$ & $\begin{array}{l}\text { QQué puedo decir? tus palabras } \\
\text { llegan directas a mi corazón y } \\
\text { reafirman todo aquello que ya } \\
\text { sé, que la luz y el amor que } \\
\text { emanas, cada día que pasa, cre- } \\
\text { cen y van llegando a más cora- } \\
\text { zones, inundando todo aquello } \\
\text { que toca allá por donde pasa. } \\
\text { Simplemente puedo decir que } \\
\text { cada día que pasa es más mara- } \\
\text { villoso amarte y sentir como me } \\
\text { amas, ver como creces y com- } \\
\text { partir cada momento de mi vida } \\
\text { con alguien tan especial como } \\
\text { tu. Sé que este puñado de pala- } \\
\text { bras no sirve para expresar todo } \\
\text { aquello que siento por ti y todo } \\
\text { aquello que me haces sentir. } \\
\text { Solo puedo decir que te adoro } \\
\text { mi vida, mi amor, mi todo. Y } \\
\text { que por favor sigas creciendo y } \\
\text { no pares de llenarnos a todos los } \\
\text { que estamos a tu alrededor de } \\
\text { esa maravilla que es tu amor, tu } \\
\text { luz y tu inteligencia. Gracias por } \\
\text { permitirme caminar a tu lado y } \\
\text { con ello hacerme especial. Gra- } \\
\text { cias de todo corazón por todas } \\
\text { tus gestos que multiplican el } \\
\text { valor de tus palabras. } \\
\text { Te amo. }\end{array}$ & 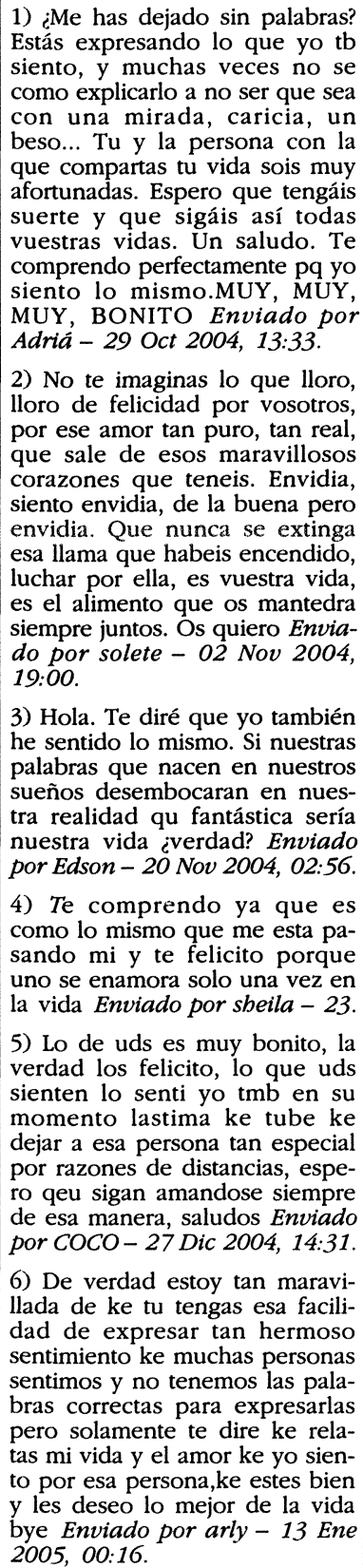 \\
\hline
\end{tabular}


El tercero de los ejemplos que presento relata la frenética relación epistolar electrónica entre dos novios, Antonio y Susana, aunque en la comunicación aparecen los seudónimos con los que entran en el chat y con los que se conocieron (ver anexo 3). Podría llamar la atención el encuentro de dos personas que se ocultan bajo nicks tan distintos, ella es "pitussy" y el "pollamán", que clarísimamente remitirían, según el esquema de la sección anterior, a dos tipologías ideológicas y sociales distintas: al amor romántico-ñoño y el popular, pero la red permite encuentros en apariencia imposibles y que desde luego serían mucho más difíciles en interacción directa. En este caso, además, hay más elementos que lo hacen especial, Susana es 10 años mayor que Antonio, está casada y tiene dos hijos. Vive en Barcelona con su marido y sus hijos en las condiciones de una familia de clase media-alta: piso en propiedad, hijos estudiando en colegios privados, coche de lujo, un sueldo de 300.000 pesetas... Antonio vive en Ciudad Real con sus padres, estudia en la universidad y trabaja esporádicamente; haber conocido a Susana en el chat y enamorarse de ella implicó romper con la novia que tenía.

Las 6 horas de frenética comunicación se desarrollan entre las 00.10 y las 5:26 del día 2 de febrero de 2000, después de que ella llega a Barcelona tras un encuentro con Antonio, un encuentro que no es el primero pues las familias respectivas ya saben de su relación: el marido de ella ["el coco" en la conversación] que ya ha escenificado la ruptura y la madre de él que se opone radicalmente a este noviazgo. Recapitulan acerca de su encuentro y replantean las dificultades de su relación. Una relación extraña pero que tiene en una película una manifestación idéntica, película que curiosamente es la que habían proyectado en el vídeo del autobús que conducía a Susana a Barcelona. A la 1:42, tiene lugar la siguiente conversación:

Pitussy: ¿sabes una cosa?

Pollamán: díme

Pi.: hoy en el bus pusieron una película ke kiero que veas.

Po.: Ok, díme cuál

Pi.: se titula secretos a escondidas o algo así

Po.: Ok, la buscaré

Pi.: pero mírala tú solo, píllala en el vídeo.

Po.: sí cielo

Pi.: es nuestra historia al dedillo.

Po.: joer

Pi.: es un calco de esto; exacto. Ya lo verás: frases y todo.

Po.: ok, cielo, la buscaré te lo prometo y la veré en cuanto la localice.

Pi.: mira es de una mujer que se enamora de un chico más joven. El estudia y ella está casada desde hace 12 años 


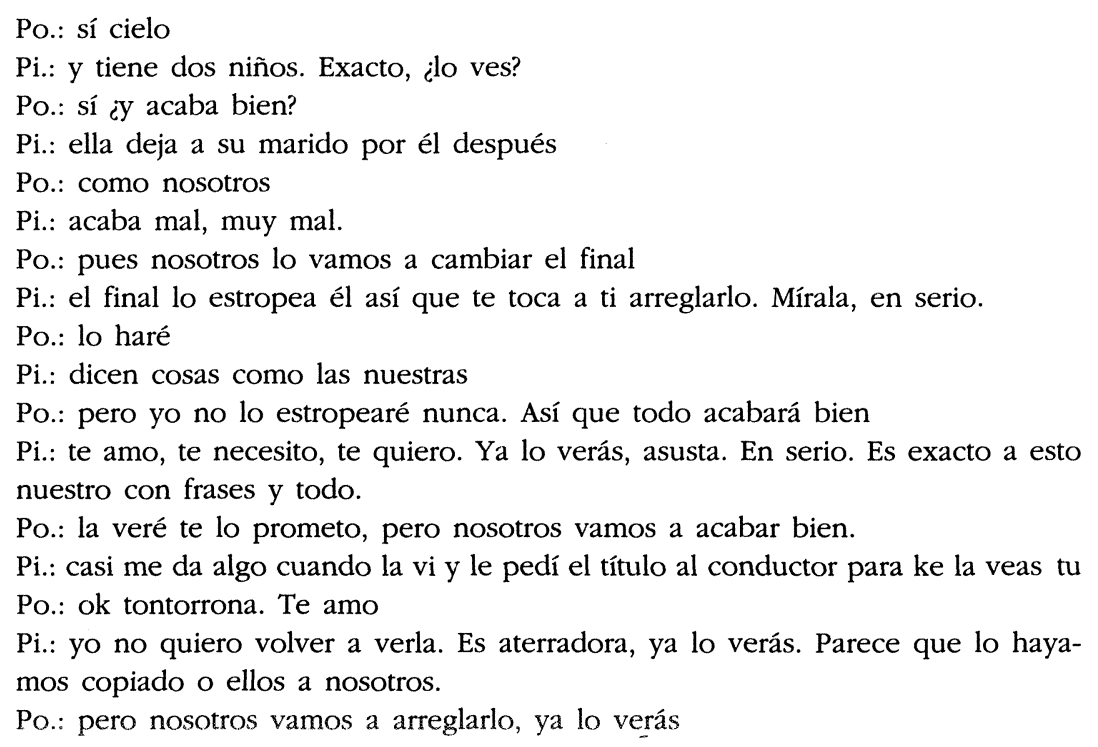

En realidad no hay ninguna película con ese título, parecido es el de la titulada Secretos ocultos, pero el conductor del autobús se debió confundir al darle el título pues esa película no tiene nada que ver. Haciendo una búsqueda en internet con alguno de los tópicos de la relación ("ella mayor que él con dos hijos....) encontramos sinopsis de la película a la que se refería: El Dormitorio. El argumento es el siguiente: "La película retrata vivamente la vida y tragedias de un grupo de gente sencilla viviendo en el estado de Maine, al norte (muy al norte) de los Estados Unidos. En el pequeño pueblo de Camden vive la familia Fowler, cuyo hijo único Frank, joven universitario, mantiene una relación romántica con Natalie, una mujer mucho mayor que él y con dos hijos. Natalie está separada de su esposo Richard, pero no se ha divorciado. Evidentemente, Richard no está muy contento con la nueva pareja de Natalie, como tampoco lo están los padres de Frank. El Dr. Fowler y su esposa Ruth creen que la relación de su hijo con la mujer no llegará a ningún lado, y pone en peligro la futura carrera del muchacho. Entonces, entre todos esos conflictos, ocurre una tragedia que cambia la vida de todos y los lleva a cometer actos muy lejanos a lo normal en sus bucólicas y pacíficas existencias". Ni Susana ni el buscador explican el final de la película. Pero no importa. Para nosotros tiene interés la reflexión que se hace Susana: parece que lo hayamos copiado o ellos a nosotros. Aquí está la cuestión que estamos tratando en estas páginas.

En realidad hay muchos más elementos de guión (o para guión) cinematográfico o de telenovela. Por ejemplo, la relación problemática de 
Susana con su marido, al enterarse, según cuenta a las 00:19, "me tiró del pelo y me llamó de todo. En cuanto entré me dio una bofetada y me llamó puta golfa, calienta niños, zorra y mala madre ke abandona a su familia y la destroza... después me echo y me dijo que no vuelva más... ahora sabe donde estoy y puede venir en cualquier momenton. Por otro lado, está el problema con la madre de Antonio que entre otras cosas piensa que una relación así hace que suspenda. A la 1:07 Susana recuerda una conversación con la madre de Antonio: "Ella me dijo ke tu no habías suspendido nunca y que esto de internet te había hecho cambiar y ke además tenías mal carácter y no te reías desde hace un par de meses ke tu abuela también lo decía y ke estabas hecho un desastre por mi culpa, ke habías adelgazado y que no comías, sólo dormías unas horas y de día y además que no estudiabas nada, ke ella no te ha visto con un libro en todo el verano y ke habías suspendido por estar así y yo no kier eso kiero ke demuestres a todo el mundo ke eres el mismon. A la diferencia de edad recurre la madre de Antonio para criticar la relación. Como escribe Antonio a las 3:37, su madre lo llama Dinio ${ }^{5} \ldots$ Susana se queda un rato escribiendo mientras Antonio va a comer algo y a las 3:43 escribe: "sabía ke esto pasaría te lo dije, ahora soy una asalta cunas ke encima quiere tu dinero... bien por $\mathrm{mi}$, a ver qué es lo siguiente igual me kedo embarazada akí para atarte o algo así. No se, a ver qué se me ocurre para pillarte... será cosa de pensarlo porque como soy una miserable ke busca jovencitos a 1000 kilómetros de casa. No se que más me falta ya aunke casi mejor me hago puta y follo con jovencitos y encima saco dinero y lo soluciono todo de golpe ¿no?.. El diálogo en torno a lo que significa la diferencia de edad en la relación de pareja, siendo ella 10 años mayor que él, se convierte entre las 3:44 y las 4:13 en un auténtico guión. Como lo es la estrategia de persecución y control de la madre: llamando a hostales cuando sospecha la presencia de ella, quitándole el móvil a Antonio, "asaltando su pcn. También es personaje de guión de/para telenovela la ex-novia de Antonio, por ella todos, incluido el marido de Susana, se enteraron de la relación, eso hace que planeen algún tipo de venganza. Están además una cohorte de personajes también extraños, como son los ayudantes cómplices, amigos del chat, la amiga íntima de ella, cómplice también, que le presta la casa en esta difícil situación. Todo ello saturado de mala conciencia de Susana, no tanto por haber abandonado al marido, sino por la suerte de sus hijos, miedo ante la violencia del marido, amistades leales... y, desde luego, mucho amor.

\footnotetext{
${ }^{5}$ Famoso y popular cubano que en ese momento mantenía una relación con una mujer mayor que él, Marujita Díaz.
} 
Las seis horas ininterrumpidas de conversación dan para mucho: para expresarse todo ese amor y cariño, también para animarse mutuamente en la complicada situación que viven, pero también para cuestiones, por ejemplo, de intendencia económica ¿con qué medios económicos podrían contar si se van a vivir juntos?, de eso hablan entre las 2:59 hasta las 3:11, momento en el que se pasa a otro asunto tras lanzar un emoticón ("Pitussy le da un largo morreo a su Pollamán"). Entre las 4:17 y las 4:35 y acompañada la conversación de varios emoticones (a las 4:17 "Pitussy le da un largo y emotivo abrazo", a las 4:20 "Pollamán le da un cariñoso y tierno beso en sus preciosos labiosn), recuerdan los mejores instantes de su reciente encuentro, momentos a los que se han referido anteriormente, pero que adquieren intensidad por el detalle con que son narrados. A las 5:25 comienzan a despedirse, se envían besos, quedan para volver "a verse" por la noche y a las 5:26 cierran la sesión.

¿De quién es el guión de esta historia? ¿de ellos mismos o de un hipotético banco de historias para telenovelas? No sabemos nada acerca del desarrollo de la historia de Antonio y Susana. Puede que haya seguido los pasos ya "guionizados" en una serie, una película o una telenovela, o quizá puede ser la historia de un próximo guión. ¿Es el guión de una historia anunciada o anunciante? Una vez más, cabe reflexionar sobre la lógica de las apropiaciones. En este caso se trata de trasvases entre vidas reales más o menos populares y guiones literarios igualmente más o menos populares. Otra vez es evidente la relación recíproca, pues las telenovelas pueden influir en la vida, pero también la vida real influye en la telenovela y no sólo porque sea un vivero inagotable de historias para novelar sino porque ahora, cada vez más, la gente anónima tiene la posibilidad de convertirse en guionista. La gente se puede apropiar y se apropia de modelos televisivos para adquirir nuevas y mejores competencias en diversos ámbitos: de seducción, de belleza, de disfrute del ocio, educación o planificación familiar. El guionista de una telenovela se apodera cada vez más de los comentarios de telenovela-adictas en los numerosísimos foros de discusión, hasta el punto de que los guiones inconclusos son una nueva alternativa que dibuja muy bien los cambios en la autoría de las historias: no es que la historia surja de la cultura popular, es que la cultura popular está escribiendo literalmente la historia.

Aunque me interesa más en este caso, y creo que es más significativa, la apropiación por parte del escritor de la escritura popular, diré algo primero de la apropiación por parte de los teleespectadores de los modelos de corrección que se proponen en las telenovelas. Un ejemplo evidente de la autoría audiovisual de comportamientos sociales se aprecia en las telenovelas mexicanas Ven conmigo y Acompáñame, cuya trama de fon- 
do tenía que ver con intereses socio-políticos: la alfabetización de mujeres y la anticoncepción. Como dicen Ortega y Solsona, muchos países han utilizado la telenovela "con la intención de difundir determinados mensajes 'educativos'. En México, "la primera telenovela realizada con intenciones de incidir en el desarrollo social fue la mejicana 'Ven Conmigo' (1975-1976) y su propósito fue incrementar la alfabetización de adultos.... Durante el año que duró su emisión, los adultos que acudían a un programa de alfabetización aumentaron en 600.000 , lo que equivalía a un crecimiento del $63 \%$... La siguiente telenovela mejicana educativa fue 'Acompáñame' y tenía como objetivo la promoción de la planificación familiar... se emitió entre 1977 y 1978 y, durante este tiempo, el número de usuarios de los servicios de planificación familiar aumentó en 560.000 en Méjico, mientras que las ventas de anticonceptivos crecieron notablemente" (Ortega y Solsona 2002: 9-10). Esta influencia benefactora dentro de la corrección política vendría a sustituir a la otra, la supuesta apropiación indeseada por manipulación y que ha sido objeto del ya viejo debate, acerca de los peligros de manipulación, evasión y alineación que saldrían de los enredos melodramáticos y alcanzarían al público - primero a las familias y después a la familia como un todo- transformándolo en un mero reducto de sueños y lágrimas, vacío de voluntades, lleno de ilusiones" (Borelli 2002: 3). No me refiero a esas formas, explícitas y burdas, de asunción por imposición, sino a otras mucho más sutiles y sugerentes que no son resultado de ningún experimento social paternalista ni de ninguna mano negra, sino que se trataría de los cambios en actitudes y comportamientos operados después de diálogos sinceros entre televidentes y el personaje de ficción, del tipo "en mi casa yo he cambiado tremendamente. Yo veo 'Sra. Isabel' y digo que no puedo ser así con mi papá o con mi mamá y trato de que se hablen" (Gomes: 2003).

En todo caso, como digo, puede tener más interés heurístico ver cómo se proyecta la escritura popular en el guión televisivo y de qué manera el guionista se apropia de ese texto escrito con mil manos. Van Tilburg ha estudiado la importancia de los teleespectadores en la conformación del guión y en el moldeamiento de actores. Así se deduce al menos del estudio de alrededor de 3000 cartas enviadas a TV Globo a actores de telenovela por parte de teleespectadores. Es una manera, pero otra es que la telenovela debe corresponderse al pulso social y a las expectativas, esa parece ser la nueva divisa y no a la inversa. El disgusto popular puede llevar a dejar de ver la telenovela... la empresa, los guionistas, y los actores, a través de las cartas que van recibiendo, pueden ir viendo cómo gusta o disgusta la historia. Puede ser que no guste. Hace unos años TV Globo tuvo que modificar el guión cerrado de una telenovela en la que los 
parámetros por los que estaba discurriendo hacían difícil llegar al esperado final feliz. La cadena iba perdiendo espectadores y - consciente de que el espectador es competente para opinar- abrió un espacio de interlocución sobre la novela. Este es uno de los ejemplos de lo que encontró:

A mi me gustan las novelas y me gusta mucho cuando una novela termina con el final feliz ya que usted escribió esa novela y le gusta que esa novela tenga mucho éxito [para ello] Usted tiene que cambiar el destino de Eugenio y Josefa. Fue un gran error que ellos fueran hermanos después de todo lo que sucedió con ellos... Ya que circuló esa historia de que ellos eran hermanos, la madre de Fátima le cuenta a ella que inventó esa historia para separarlos a los dos por miedo a que Jeanette los descubriese. Es cierto que la novela es suya, usted la escribió y hace lo que quiera con ella, pero los espectadores tenemos derecho a dar nuestra opinión, porque si nosotros los espectadores no vemos sus novelas, ustedes no tienen ningún éxito. No aguanto más ver la novela de la manera en que está hecha, la gente ya no tiene ninguna diversión, lo único que tiene son las novelas y las novelas lo único que hacen es dejar a la gente aburrida, es mejor ni verlas. Antiguamente pasaban muchas novelas buenas, la gente se volvía loca por llegar a la hora para verla, ahora no, la gente no, la gente solo las ve para tener rabia (Van Yilburg 1996).

Hoy más que nunca estamos en situación de poder ver una vida común en un escenario público (impreso, televisivo, en la red); podemos ver cómo la realidad orienta la ficción. La pléyade de páginas webs que informan de los sentimiento de los teleespectadores respecto a las telenovelas, las conversaciones en chats de éstos entre sí y con los actores o los guionistas, las peticiones recíprocas para que se cuenten el argumento de capítulos perdidos o para que televidentes de otros países que ya han visto una telenovela cuenten avances de la misma o la nueva y pujante moda de las foronovelas en la que se disuelve la frontera - casi- entre la autoría y la recepción de la ficción. En fin, todo el arsenal de recursos disponibles para que la voz anónima adquiera publicidad está haciendo que la necesidad de discursos sobre el amor en las culturas populares se abastezca en sí misma, sin necesidad de tomar modelos que "descienden" desde la cultura-literaria-"culta". Un autoabastecimiento que olvida otras formas de expresión del amor porque, como ha señalado Manuel Gutiérrez (1997), este amor latino va unido a la idea de felicidad ¿qué más y qué mejor cosa se le puede pedir al amor? ¿qué necesidad hay de retóricas "cultas"? Todos los argumentos, todas las posibilidades, todo lo imaginable, está en la telenovela. No es que hayan aflorado tipologías amorosas raras por extrañas y por minoritarias, sino que en el proceso de apropiación popular de la pluma y la imaginación se satura el asunto. Para muestra ciertamente sólo un botón de diálogos, comentarios, y recomendaciones en internet: 
http://www.quovadis.com.ar/telenovelas/amorreal/dialogos/ http://www.tvazteca.com/telenovelas/t anteriores/ellas/ficha.shtml http://www.telenovelasonline.org/apuesta.html http://www.telenovelas.com.ar/archivo/destacado02.html http://www.alma-latina.net/ViasdelAmorLas/comments.shtml http://www.telenovelasperu.com/historia/historia.htm http://www.network54.com/Forum/22124 http://foro.univision.com/univision/board?board.id=72359095121 http://www.fotech.cl/ http://www.telenovelasperu.com/ http://www.network54.com/Forum/viewall?forumid $=43187 \& \mathrm{it}=363$

\section{LITERATURA, VIDA COTIDIANA Y MECANISMOS RECÍPROCOS DE APROPIACIÓN}

Se trataba en este artículo de terciar en el debate entre la transitividad o intransitividad de la literatura. He hablado de la transitividad literaria pero constreñida y modulada ésta por avatares diversos, ligados al contexto. El amor y las relaciones de pareja estudiadas pueden ser reflejo y espejo literario o metaliterario con mayor o menor intensidad; reflejo y espejo, a su vez, de y en distintas sociedades, que de manera aproblemática podría calificar como populares y de elite. Podemos encontrar, de ese modo, cuatro posibles tipos de vinculaciones recíprocas. Entre metaliteratura y sociedad popular; entre metaliteratura y sociedad de elite; entre literatura y sociedad de elite, y entre literatura y sociedad popular. He sugerido que la relación entre Manuel Ribera y Juana Carneros es reflejo literario (la sociedad popular construida desde la literatura) y que la relación entre Antonio y Susana, por el contrario, parece ser espejo para la ficción (desde la realidad popular a la metaliteratura en los guiones de telenovelas) y finalmente, el caso más complejo, la relación entre Miguel y Sebastiana lo he abordado como centro de una doble proyección, literaria y metaliteraria. El análisis de esta última, a mi juicio, es también interesante porque presenta una relación vertical, en el sentido de "abajo" hacia "arriba", de la metaliteratura a las elites sociales. Aunque no es un asunto muy tratado por las ciencias sociales, es ciertamente muy interesante porque alude a la complejidad de las relaciones entre cultura de clases dominantes y cultura de clases populares, como ha dicho Carlo Ginzburg:

Explicar estas analogías mediante la simple difusión de arriba abajo, significa aceptar sin más la tesis insostenible según la cual las ideas nacen exclusivamente en el seno de las clases dominantes. El rechazo de esta explicación simplista 
implica, por otra parte, una hipótesis mucho más compleja sobre las relaciones que se producen durante este período entre cultura de las clases dominantes y cultura de las clases subalternas (1994: 180).

A la hora de cualificar las transferencias caben dos consideraciones. Una acerca de lo que se modifica en el camino; para dilucidarla habría que entrar en textos de intermediación en textos fronterizos, textos de negociación entre la "gran tradición" y la "pequeña tradición" (tal como refiere María Cátedra 1997: 24). Y otra, en la que me detengo más, que es la que tiene que ver con el asunto de lo que he llamado mecanismos de apropiación, que vienen a ser lo que Ginzburg ha denominado las claves de lectura; concepto empleado para escudriñar en la lógica de Menochio - el molinero friulano protagonista de El queso y los gusanos- a la hora de subrayar partes de un texto literario y desechar otras. Más importante que el texto es la clave de lectura; el tamiz que Menochio interponía inconscientemente entre él y la página impresa: un tamiz que pone de relieve ciertos pasajes y oculta otros, que exaspera el significado de una palabra sacándola del contexto, que actuaba sobre la memoria de Menochio deformando la propia lectura del texto. Y ese tamiz, esa clave de lectura, nos remite continuamente a una cultura distinta de la expresada por al página impresa: una cultura oral (Ginzburg 1994: 68).

A veces, por ejemplo, las recepciones literarias en la sociedad popular producen elaboraciones totalmente desconcertantes que implican un desacuerdo completo con el autor. En otros casos, para el mismo binomio (literatura-sociedad popular), la apropiación no parece tal porque se oyen los ecos de una primigenia autoría popular. En otro texto de Ginzburg se sugiere que cuando un texto nace de la cultura oral popular el descenso es más fácil y se hace mayormente inteligible. Refiere en Ojazos de madera, una anécdota que le gustaba contar al conde Tolstoi, su hija ule dijo en una ocasión a una vieja campesina que le ayudaba en casa que estaba de mal humor. "si lees a Marco Aurelio - le respondió la vieja- se te pasará toda la tristeza" "¿qué Marco Aurelio? Y ¿por qué Marco Aurelio? Preguntó Alexandra Lvovna". "Seguro, seguro - le explicó la vieja-, es un libro que me dio el conde. En el está escrito que todos moriremos. Y si tenemos la muerte ante nosotros, tampoco valen nada nuestras tristezas". En cuanto pienses en la muerte te sentirás más ligero. Yo, cuando tengo alguna pena en el corazón siempre digo: “eh, muchachos, leedme a Marco Aurelio'" (Ginzburg 2000: 32). Según Ginzburg, Tolstoi consideraba que la vieja campesina era capaz de comprender a Marco Aurelio "porque, además, ciertas meditaciones de Marco Aurelio se alimentaban de un género literario popular como las adivinanzas" (ibid.: 33). Caro Baroja, un tolstosiano confeso, reconoce sin embargo que en la formación de su 
narración histórica (narraciones literarias que pretenden retratar la realidad), quizá Tolstoi no fue capaz de comprender al Napoleón histórico, sino que construyó un arquetipo. De esa manera, el arquetipo que crea Tolstoi no sería el producto de una decantación, de un factor común, resultado de un consenso social, sino de una elección más o menos intencionada. La pregunta que cabe es esa que se plantea Mary Douglas (1998: 15): "por qué las personas hacen distintas inferencias a partir de los mismos datos"; podríamos decir que la respuesta tienen que ver con que los datos no son neutros, sino que están cargados de ideología. Así, la clave de lectura o el mecanismo de apropiación está en relación con la posición del lector. La cuestión no es que la realidad pueda ser de diferente manera a cómo la vemos; la clave está en cómo la miramos.

Claves de lectura o mecanismos de apropiación y eso para extraer realidad y escribirla y para leerla. Así puede ser que el Napoleón de Guerra y Paz sea un personaje tolstosiano y por tanto desdibujado o descarnado. Pero también puede suceder que la Serrana de la Vera y Don Juan Tenorio hayan buscado y conseguido encarnarse. Dice Caro Baroja:

No seré yo quien niegue, por otra parte, que el personaje novelesco, o el arquetipo, influye luego en personas reales, arrastradas por la fuerza de la narración literaria. Porque muchas veces, en la vejez de mi tío, Pío Baroja, veía llegar a casa tipos que, más que buscar autor, parecían reclamar la paternidad del autor en cuestión, y de ahí arranca, a mi juicio el significado de expresiones tales como la de: es un personaje barojiano o galdosiano. Es un tipo valleinclanesco o un carácter unamunesco. Pero Galdós o Baroja, Unamuno o Valle Inclán, actúan antes y con su propio fin. Como don Juan ha actuado sobre la idea que tenemos de un hombre donjuanesco (Caro Baroja 1979: 127).

Así, a la conclusión contundente que habría enunciado Augusto Monterroso: "el camaleón es del color según el cristal con que se mira", habría que añadir que el cristal con que se mira es según el camaleón.

\section{BIBLIOGRAFÍA CITADA}

BARTHES, ROLAND. 1997. Fragmentos de un discurso amoroso. Madrid: Círculo de Lectores.

BORELli, Silvia. 2001. “Telenovelas brasileiras. Balanços y perspectivas». Sao Paulo em perspectiva 13 (3): 29-36

CARO BAROJA, Julio. 1979. Ensayos de cultura popular española. Madrid: Dosbe.

CÁtEDRA TOMÁs, MARÍA. 1997. Un santo para una ciudad. Barcelona: Ariel.

CLIFFORD, JAMES. 1991. "Introducción: verdades parciales", en James Clifford y George Marcus (eds.), Retóricas de la Antropología. Gijón: Júcar.

CORBIN, ALAIN. 1998. "Los ritos de la vida privada burguesan, en Philippe Ariès y George Duby (dirs.), Historia de la vida privada 4. De la Revolución Francesa a la Primera Guerra Mundial: 419-268. Taurus: Madrid. 
DEMARS-SION, VÉRONIQUE. 1991. Femmes séduites et abandonées au XVIIIe siècle... L'exemple du Cambrésis. Lille: ESTER.

DOUGLAS, MARY. 1998. Estilos de pensar. Barcelona: Gedisa

FouCAUlt, MichaEl. 1986. "Consideraciones inéditas y póstumas sobre literatura". El País 11-11-1986.

FuENZALIDA, VALERIO. 1996. "La lectura de un texto televisivo. Telenovelas y cuestiones metodológicas. Revista Diálogos 44. http://www.felafacs.org/dialogos/pdf44/ dialogos44.asp

García CANClini, NÉSTOR. 2004. Diferentes, desiguales y desconectados. Mapas de la interculturalidad. Barcelona: Gedisa.

GEERTZ, CLIFFORD. 1990. La interpretación de las culturas. Barcelona: Gedisa.

GinzBurg, CARLo. 1994. El queso y los gusanos. Barcelona: Muchnik.

- 2000. Ojazos de madera. Nueve reflexiones sobre la distancia. Barcelona: Península.

GOMES M., MARCIA. 2003. "Telenovelas: Papeis sociais, identidade cultural e socializaçao", en XXVI Congresso Anual em Ciência da Comunicação. http://www.intercom.org.br/ papers/congreso 2003 .

GoICOVIC DONOSO, IGOR. 1998. Sujetos, mentalidades y movimientos sociales en Chile. Santiago de Chile: Cipda.

GutiérRez ESTÉvez, MANUEL. 1997. "La felicidad democrática y el triunfo del amor", en Manuel de la Fuente y M. Ángeles Hermosilla (eds.), Etnoliteratura: una antropologia de ¿lo imaginario?: 165-186. Córdoba: Universidad de Córdoba.

HERNÁNDEZ GONZÁlEZ, MANUEL. 1998. Mujer y vida cotidiana en Canarias en el s. XVIII. Santa Cruz de Tenerife: Centro de Cultura Popular Canaria.

FUENTE LOMBO. MANUEL DE LA. 1979. "Apuntes para una meta-antropología del conocimiento científico y del estudio de la cultura". Étnica 15: 69-82.

- 1995. Etnoliteratura. Un nuevo método de análisis en Antropología. Córdoba: Universidad de Córdoba.

- y M. ÁNGEles HeRmosilla (eds.). 1997. Etnoliteratura: una antropología de ¿lo imaginario? Córdoba: Universidad de Córdoba.

LÓPEZ GARCÍA, JULIÁN. 2003. Ideologías y ritos populares de nacimiento, noviazgo, matrimonio y muerte en Ciudad Real. Ciudad Real: Biblioteca de Autores Manchegos.

MANTECÓN MOVELLÁN, TOMÁs A. 2002. "Mujeres forzadas y abusos deshonestos en la Castilla Moderna". Manuscrits 20: 157-185.

MARTIN-FUGIER, ANNE. 1998. "Los ritos de la vida privada burguesa", en Philippe Ariès y George Duby (dirs.), Historia de la vida privada 4. De la Revolución Francesa a la Primera Guerra Mundial: 199-268. Taurus: Madrid.

Molins, Marqués de. 1874. La Manchega. Madrid: Imp. R. P. Infante.

ORTEGa, MARTA y M. SOlSONA. 2000 "Demografía, cambio familiar y telenovelas. De la realidad a la representación y viceversa. Papers de Demografía 181: 1-24.

RODRíguez, PABLo. 1991. Seducción, amancebamiento y abandono en la colonia. Santa Fe de Bogotá: Ed. Ealon, Colección Historia 2.

TESTÓN NúÑEZ, ISABEL. 1985. Amor, sexo y matrimonio en Extremadura. Badajoz: Biblioteca Popular Extremeña.

VAN YilburG, JOÃO. 1996. "La lectura de un texto televisivo. Telenovelas y cuestiones metodológicas". Revista Diálogos 44. http://www.felafacs.org/dialogos/pdf44/ dialogos44.asp 


\section{ANEXO 1}

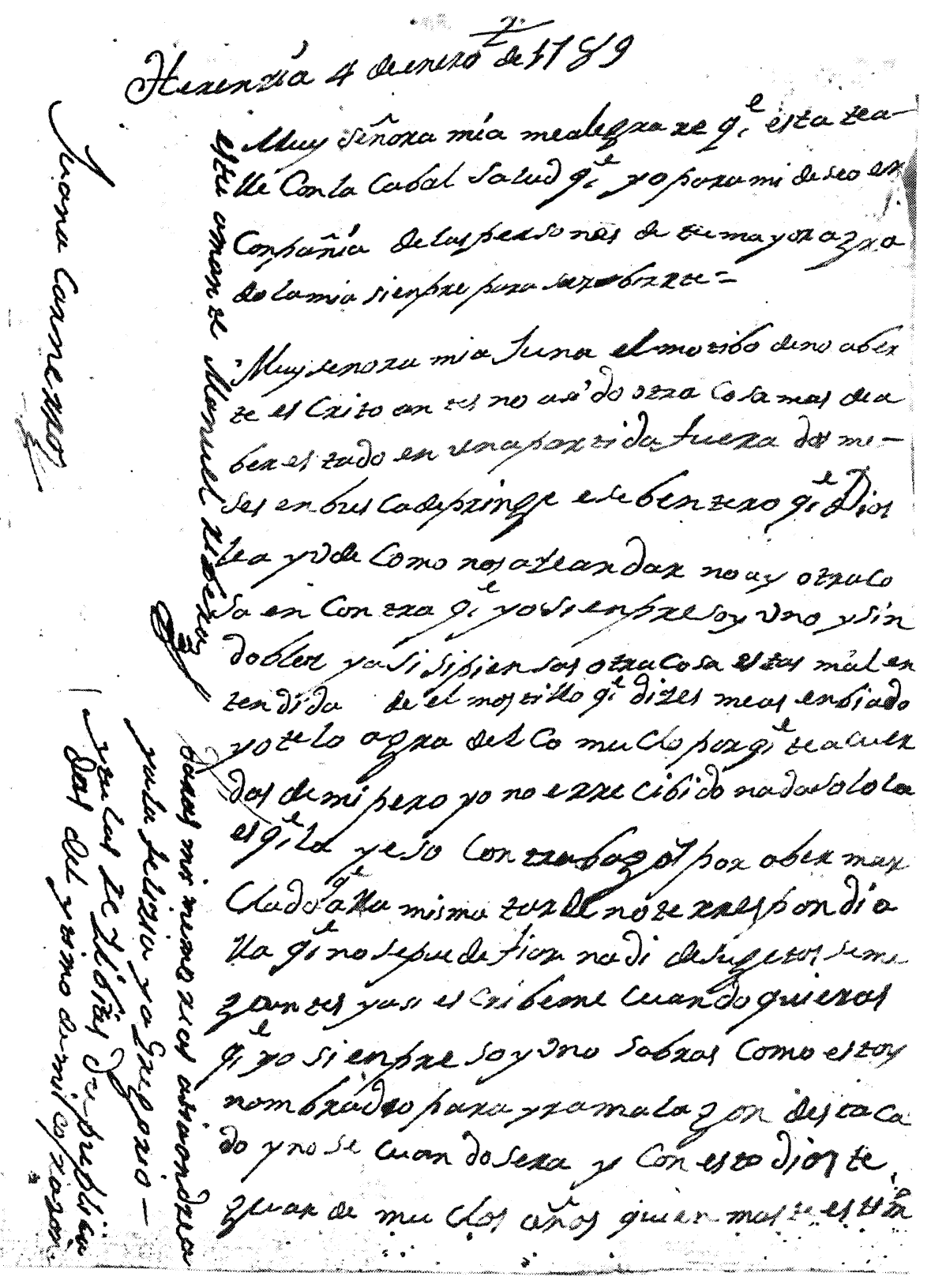




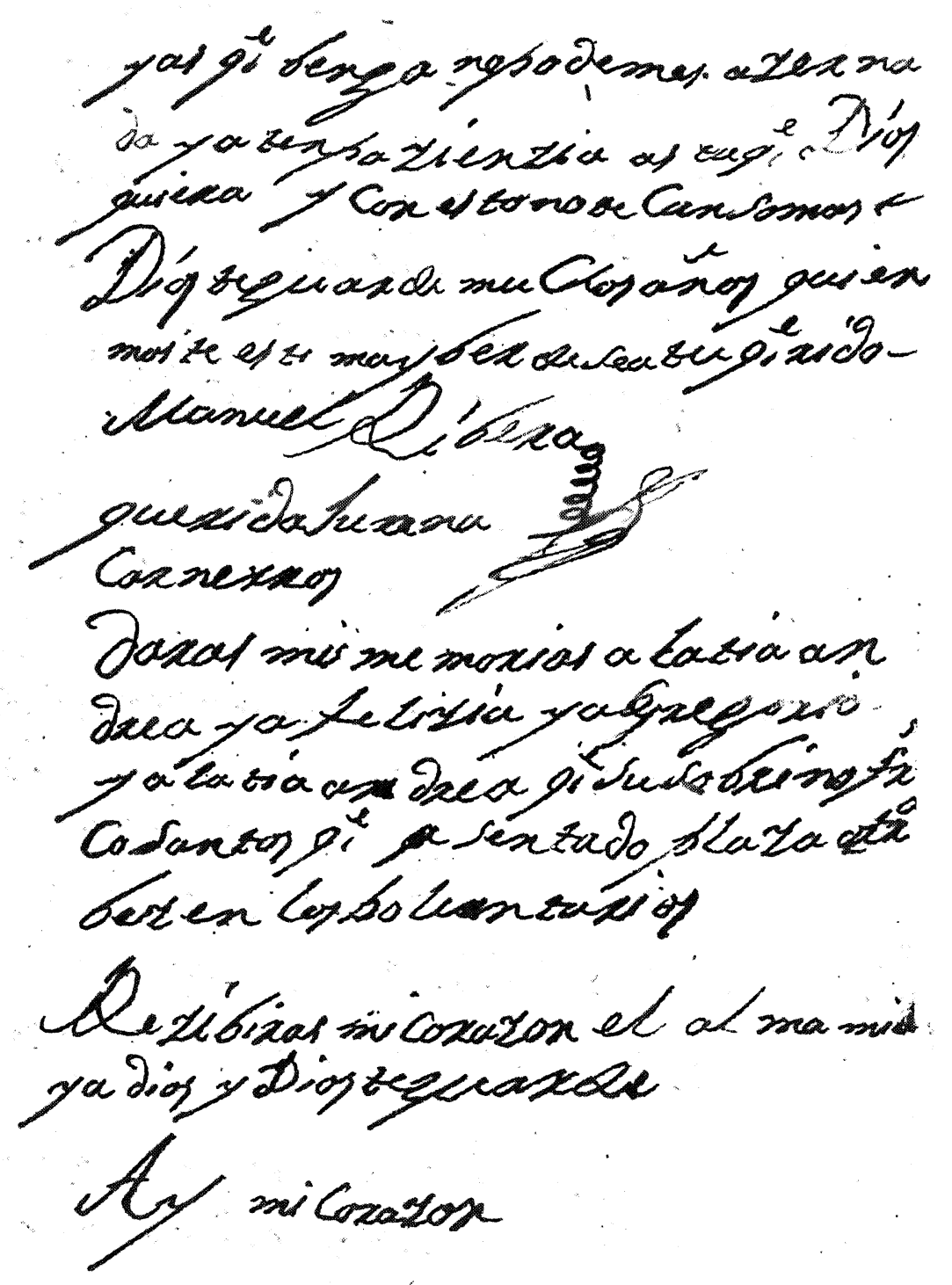




\section{ANEXO 2}
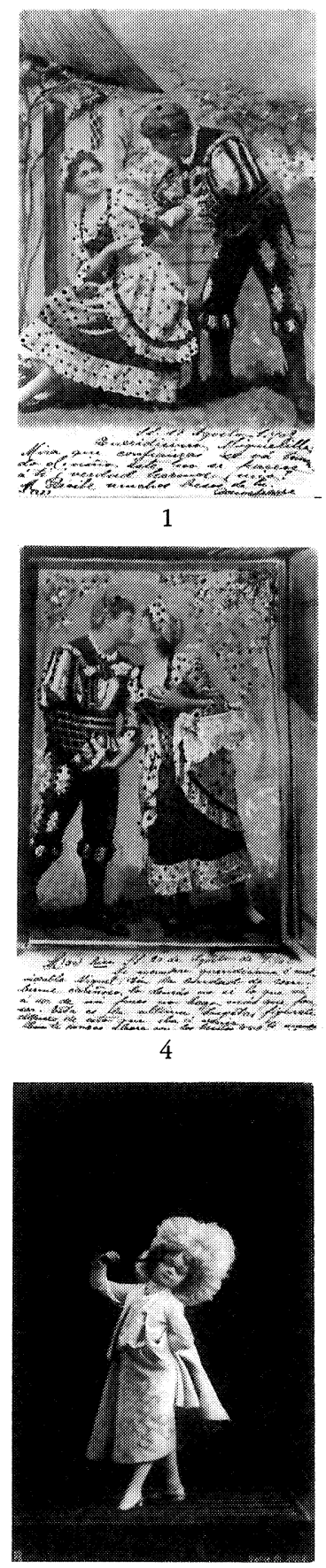

7

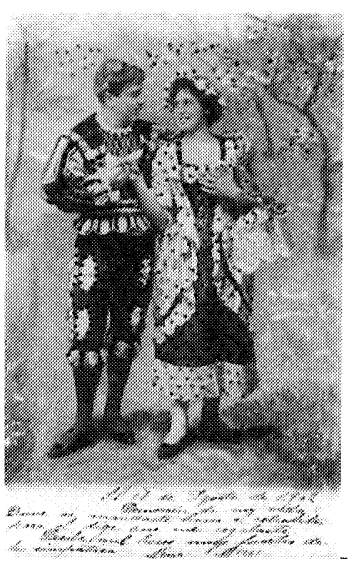

2
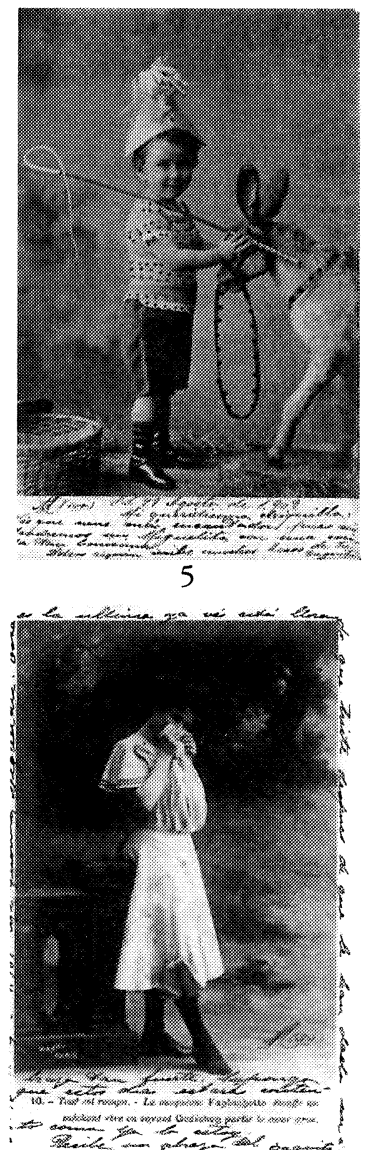

9
JULIÁN LÓPEZ GARCÍA

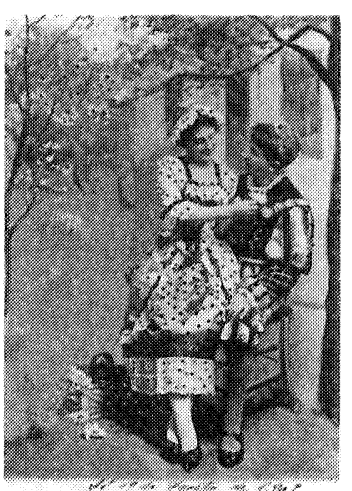

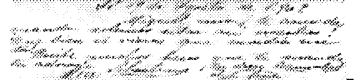

3

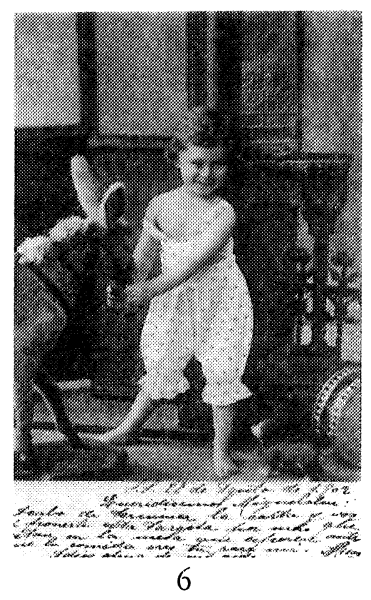

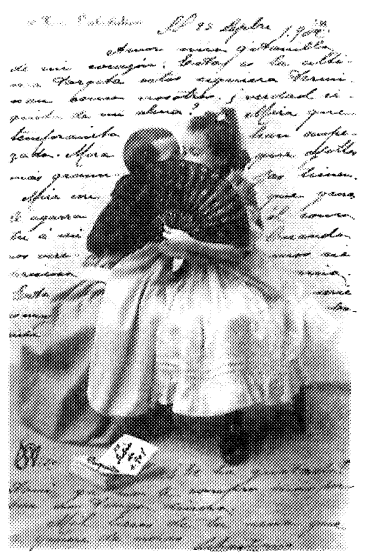

10 


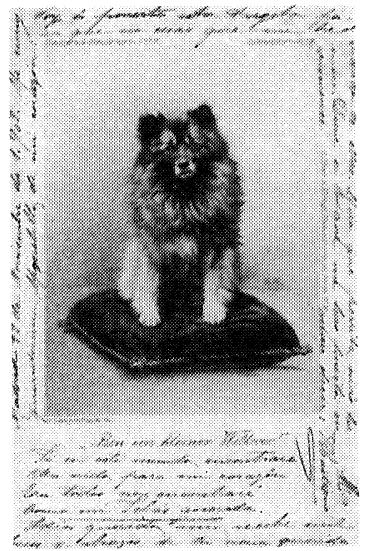

11

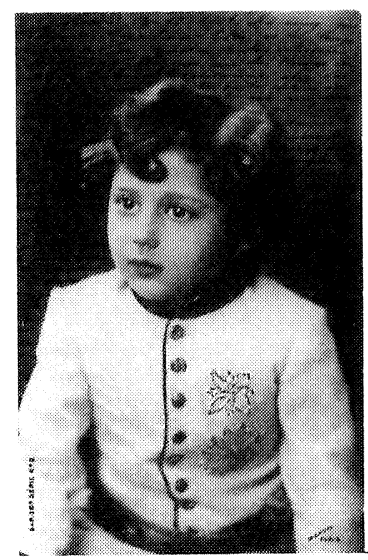

14

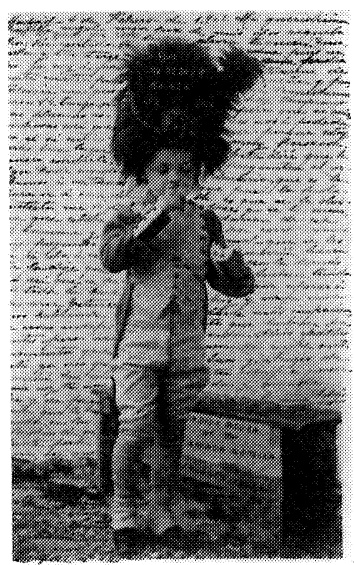

19

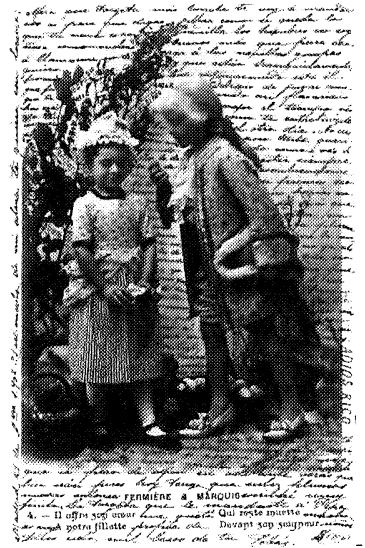

12

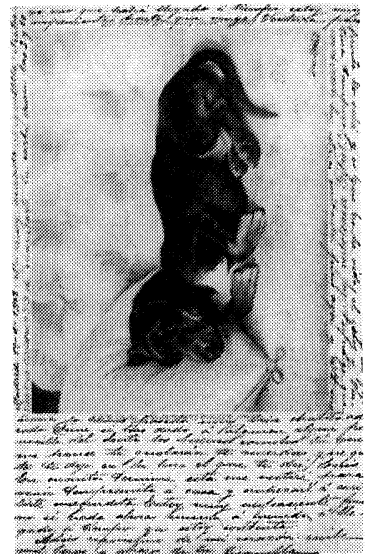

16

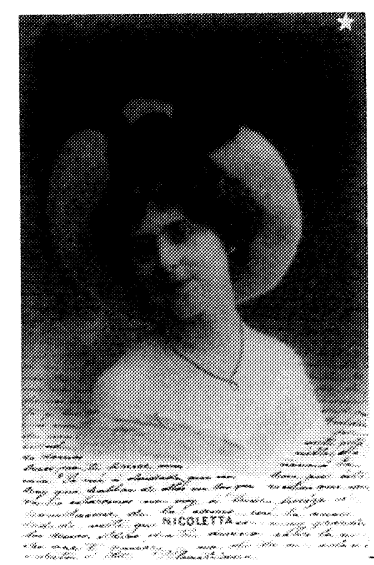

20

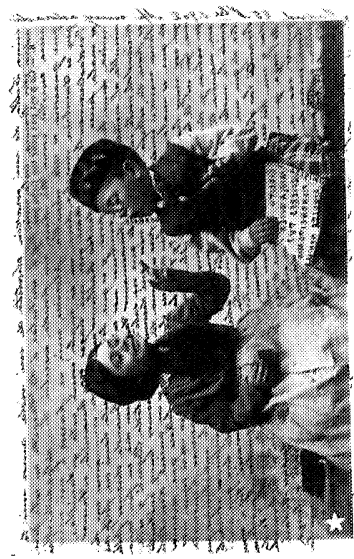

13

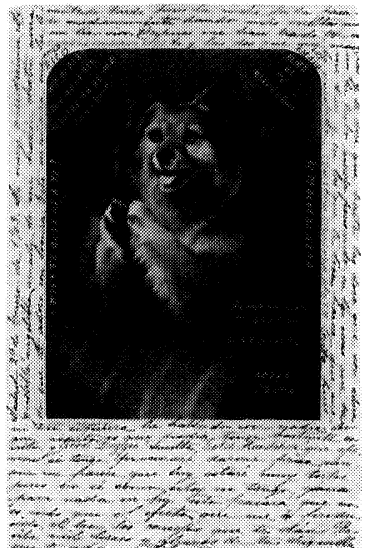

18

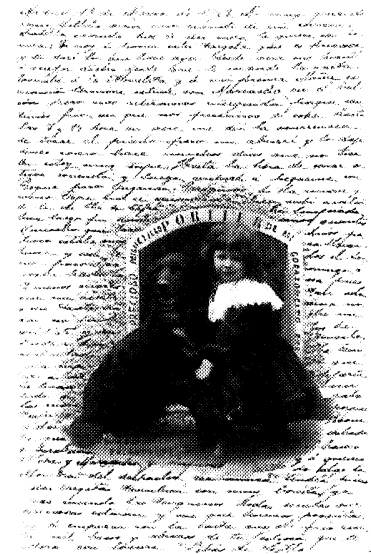

21 


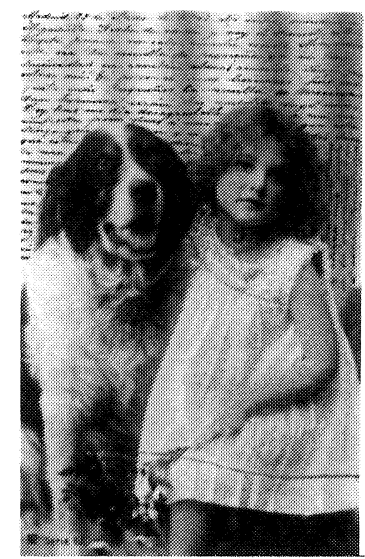

22

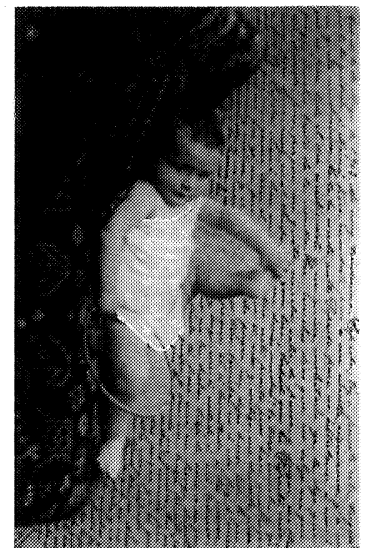

25

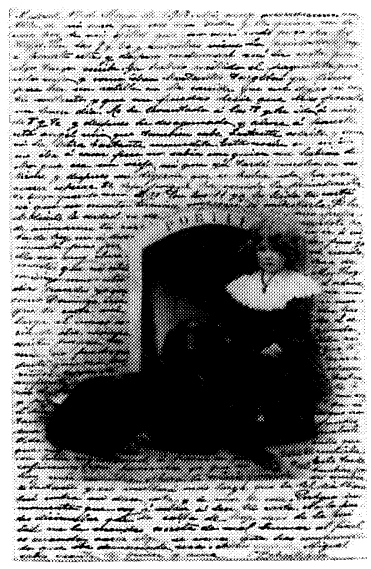

28

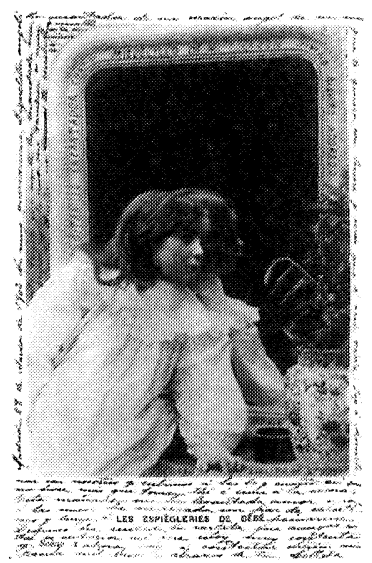

23

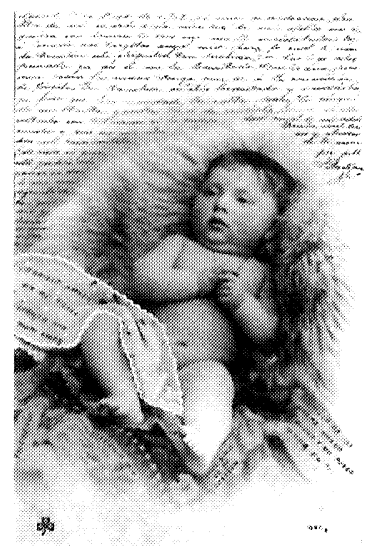

26

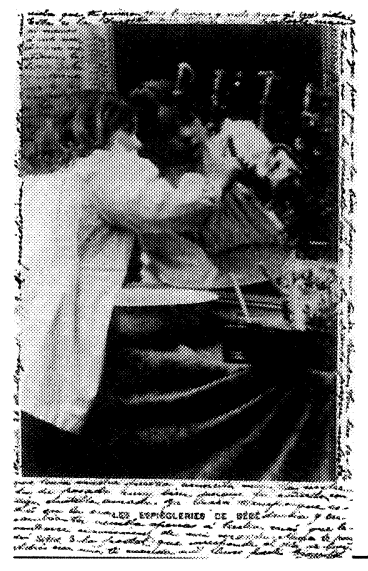

29

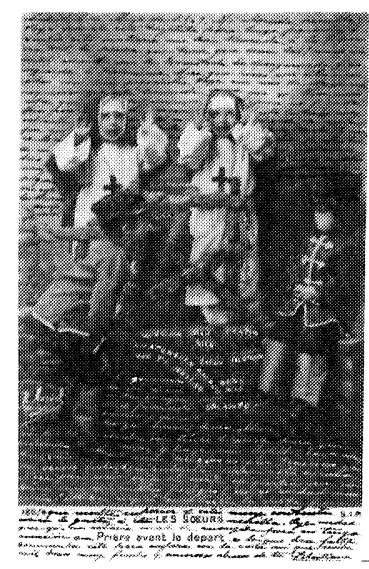

24

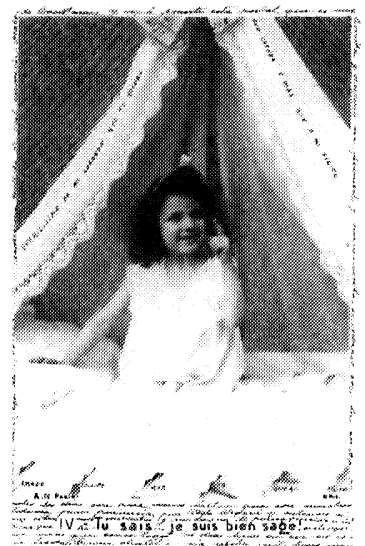

27

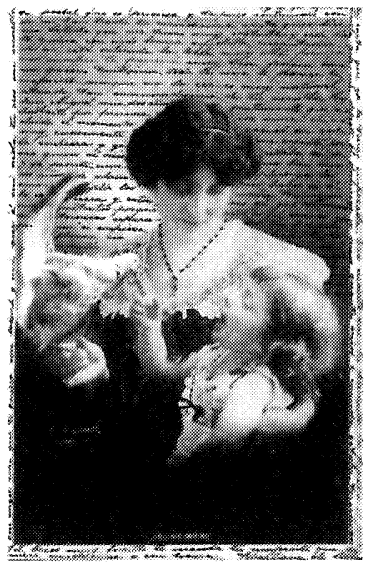

30 


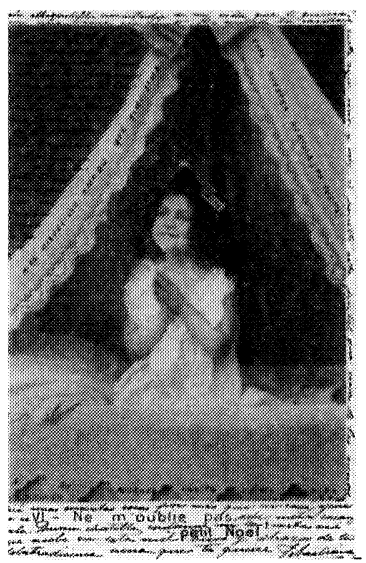

31

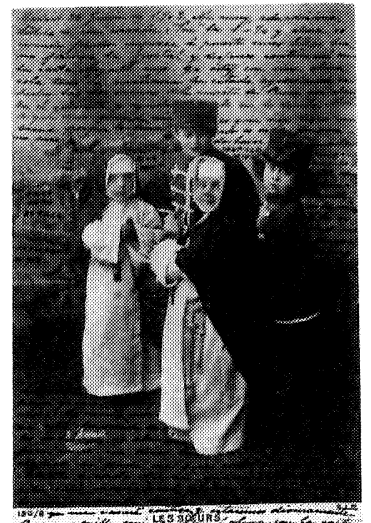

$3=\frac{7}{3}$ rot

34

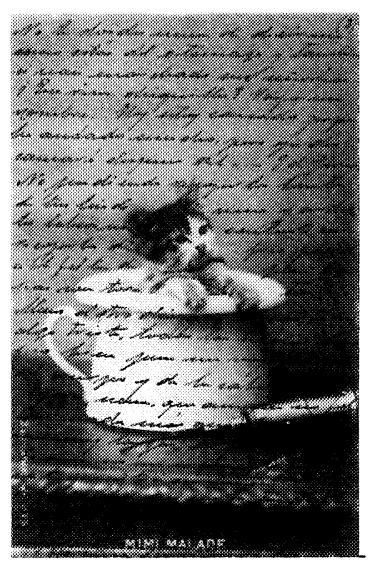

39

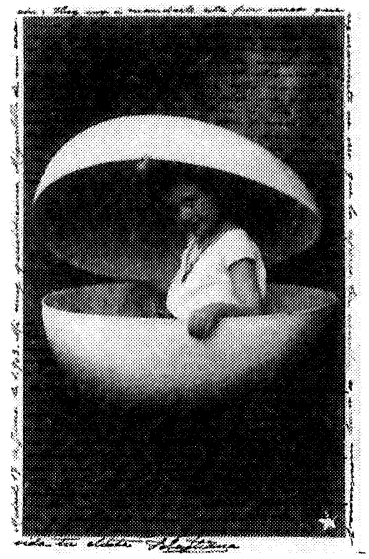

32

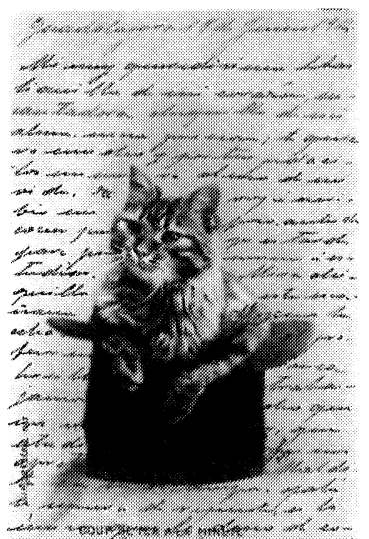

37

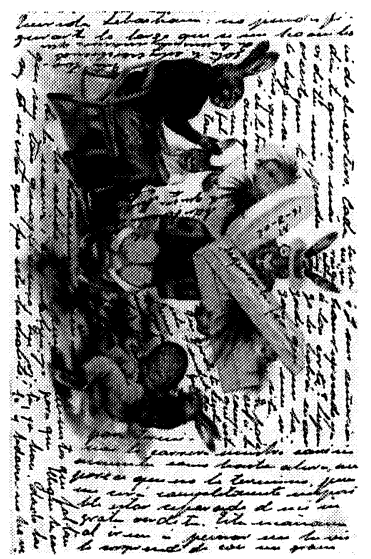

47

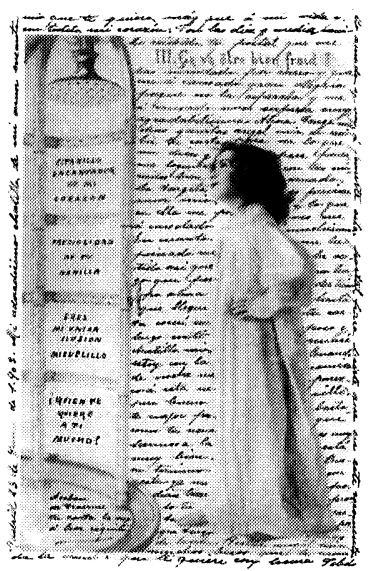

33

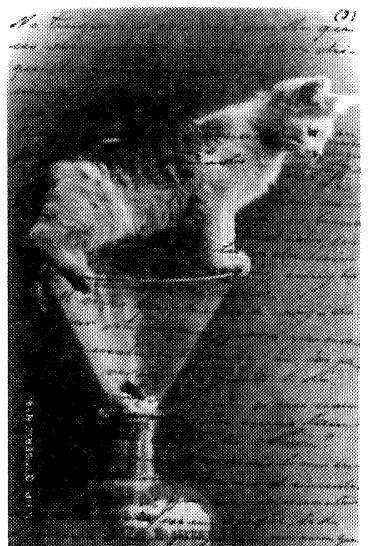

38

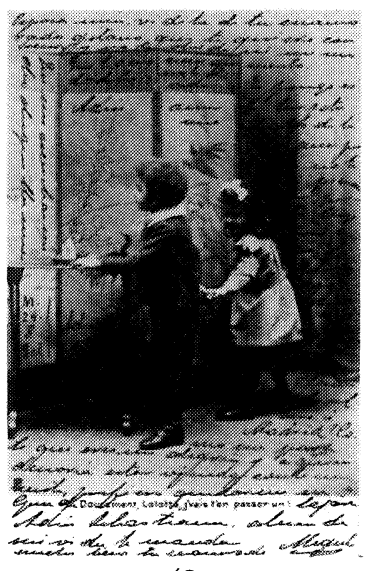

48 

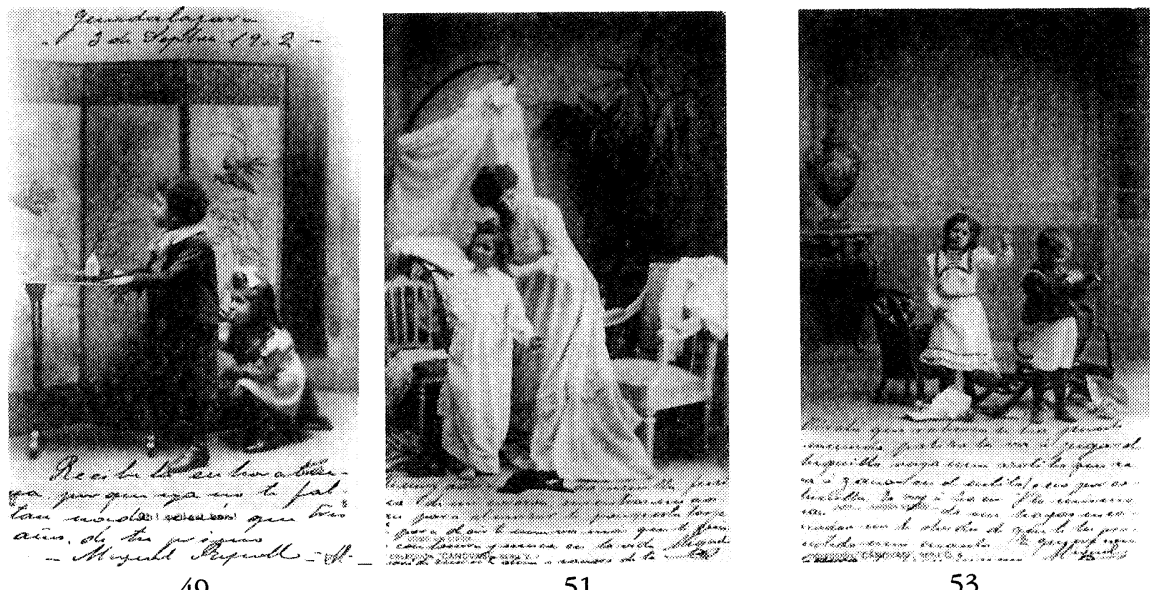

49

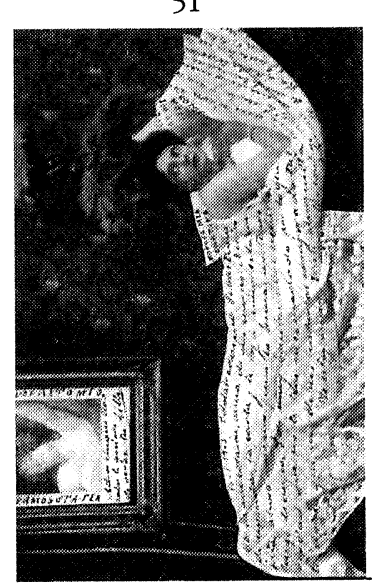

53

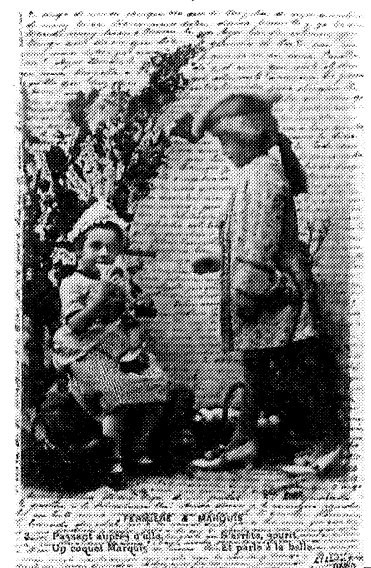

56

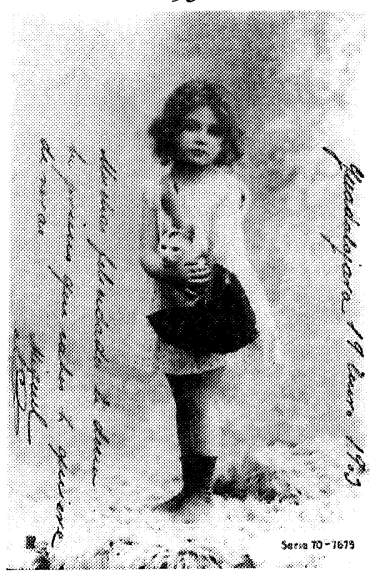

55

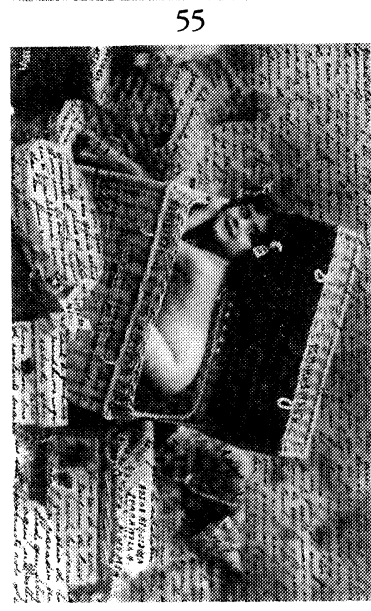

58

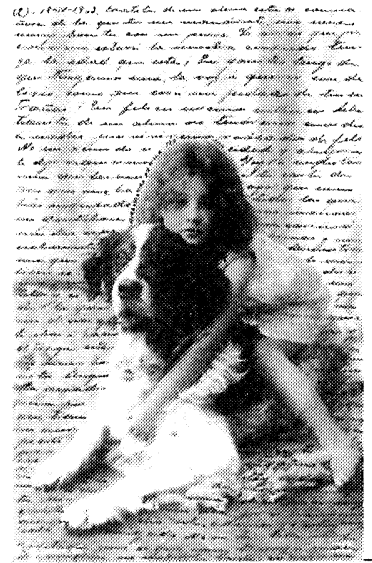

59

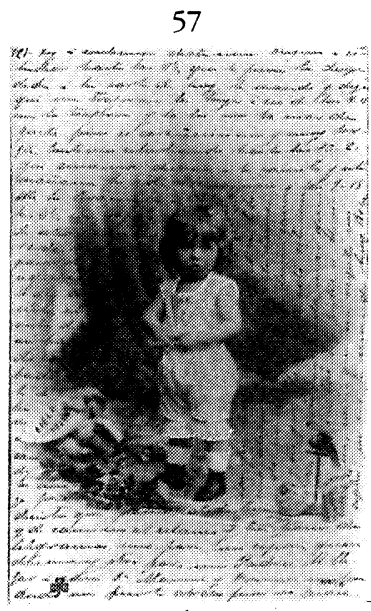

60 


\section{ANEXO 3}
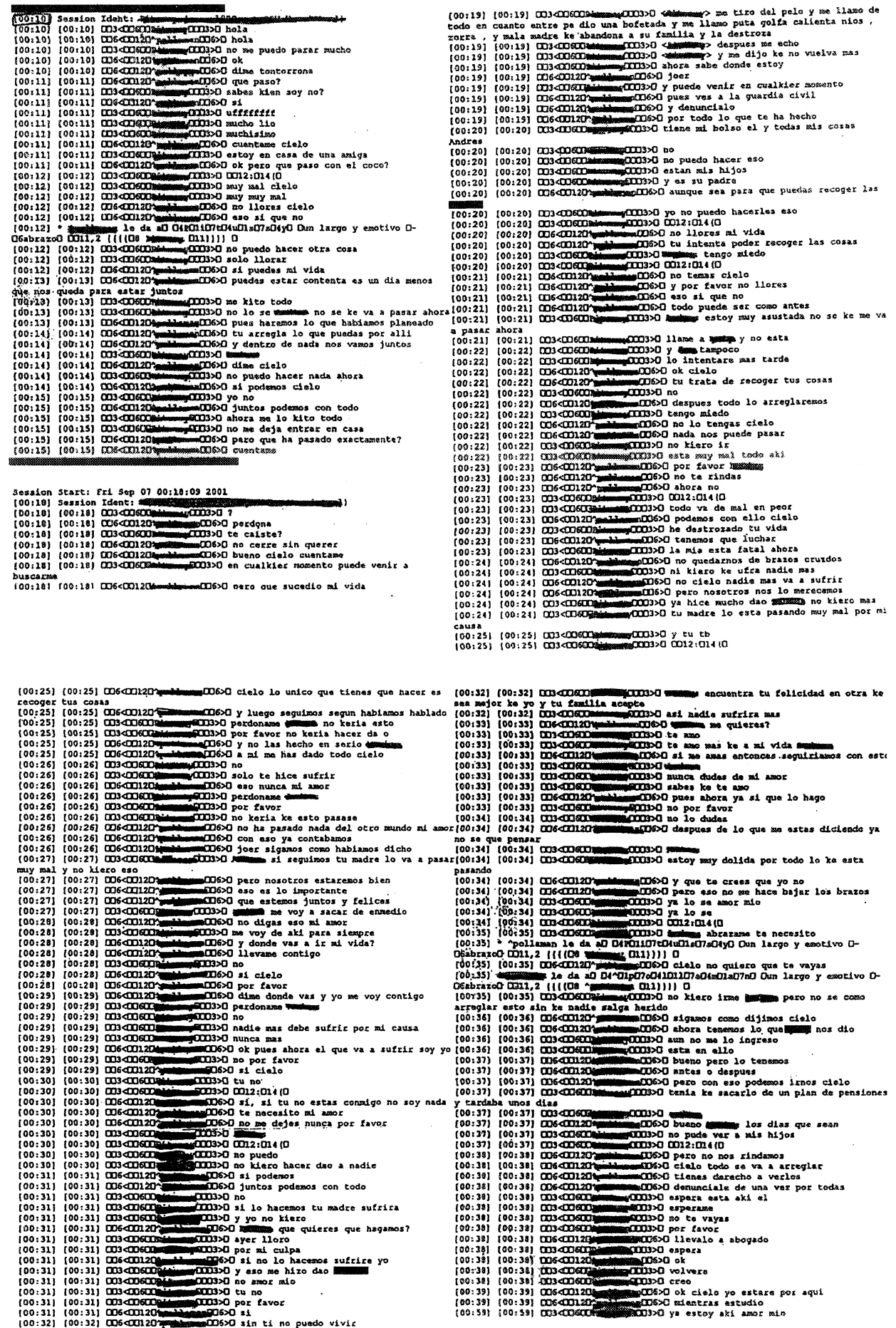

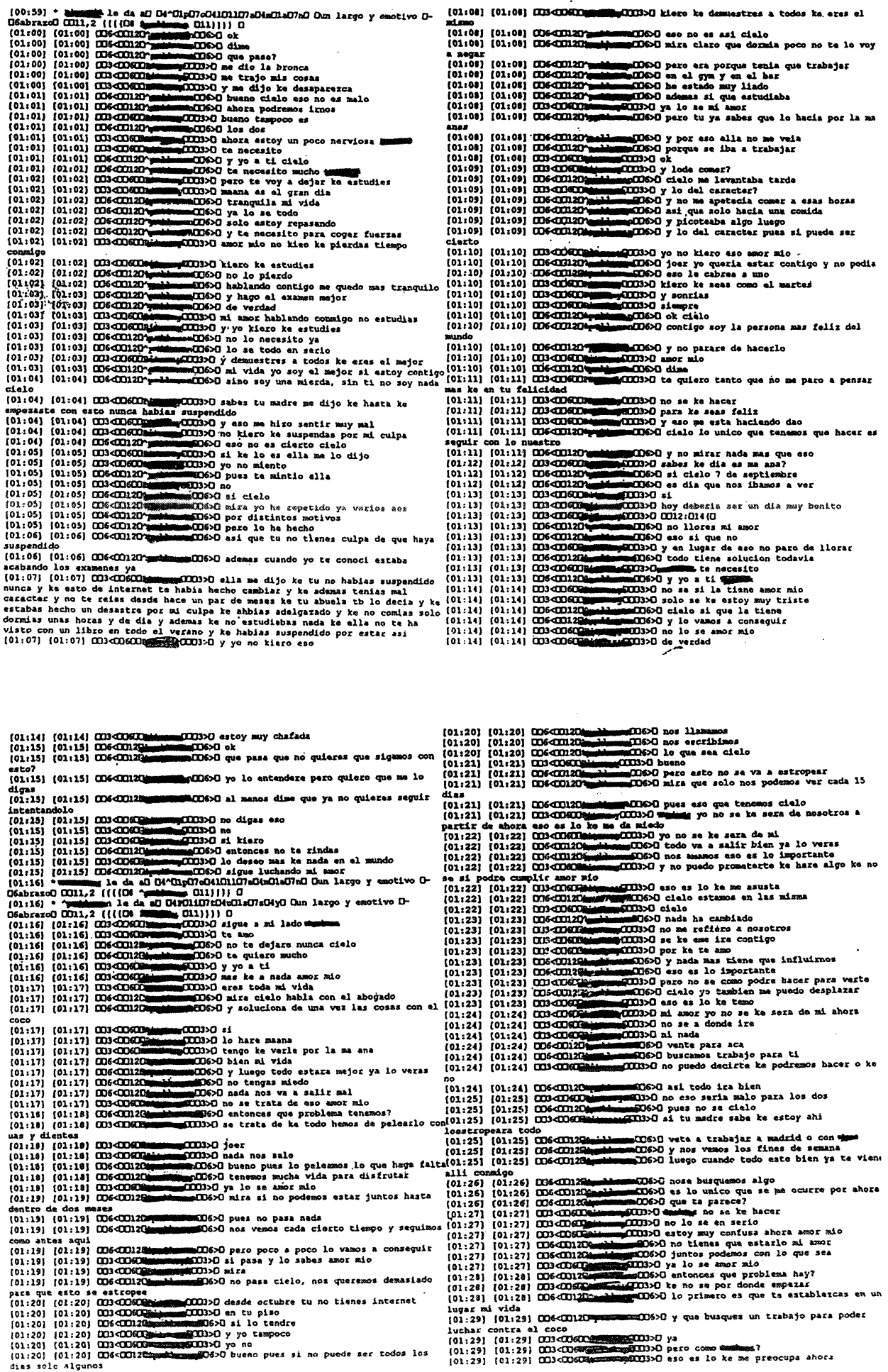

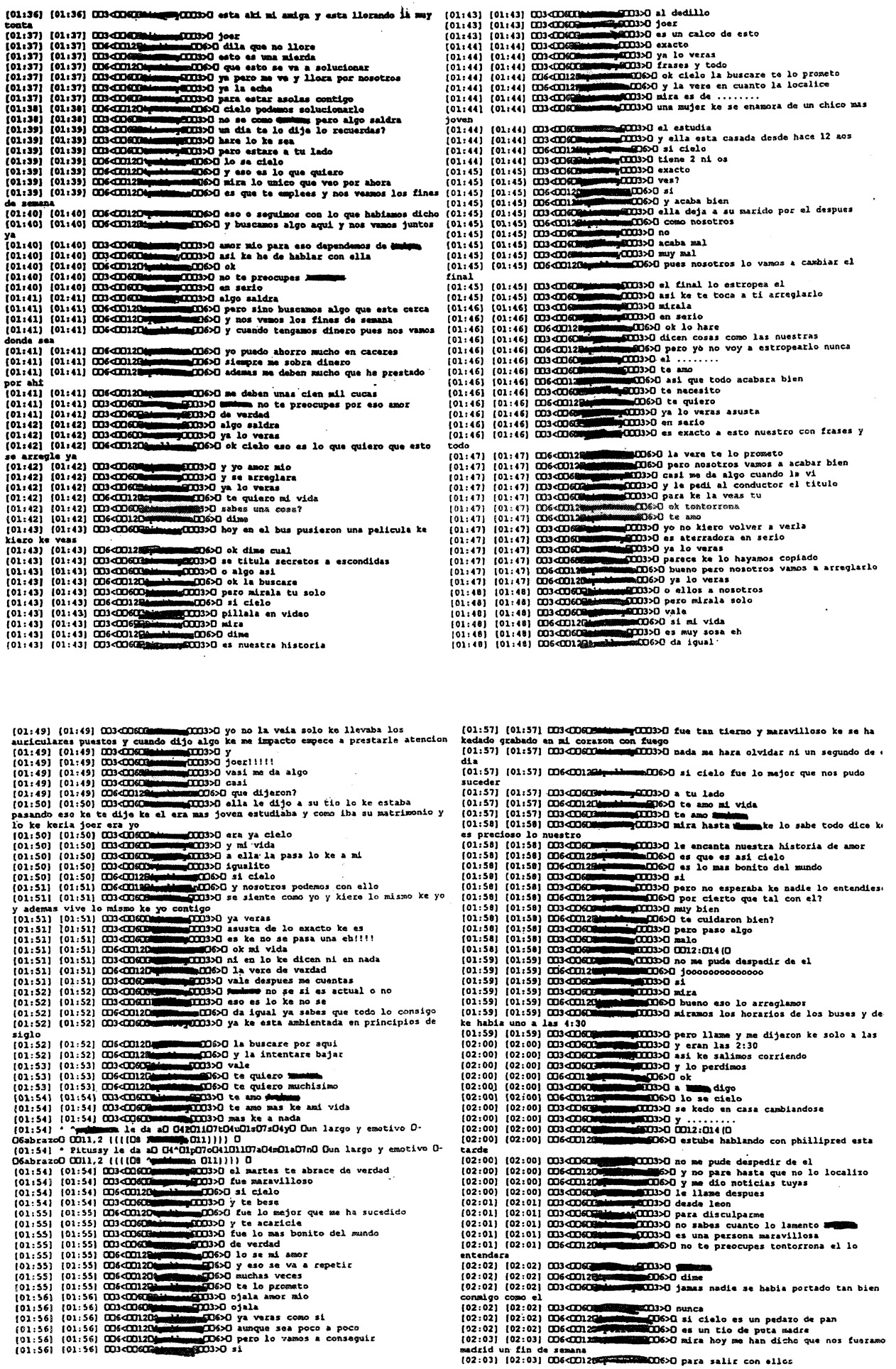

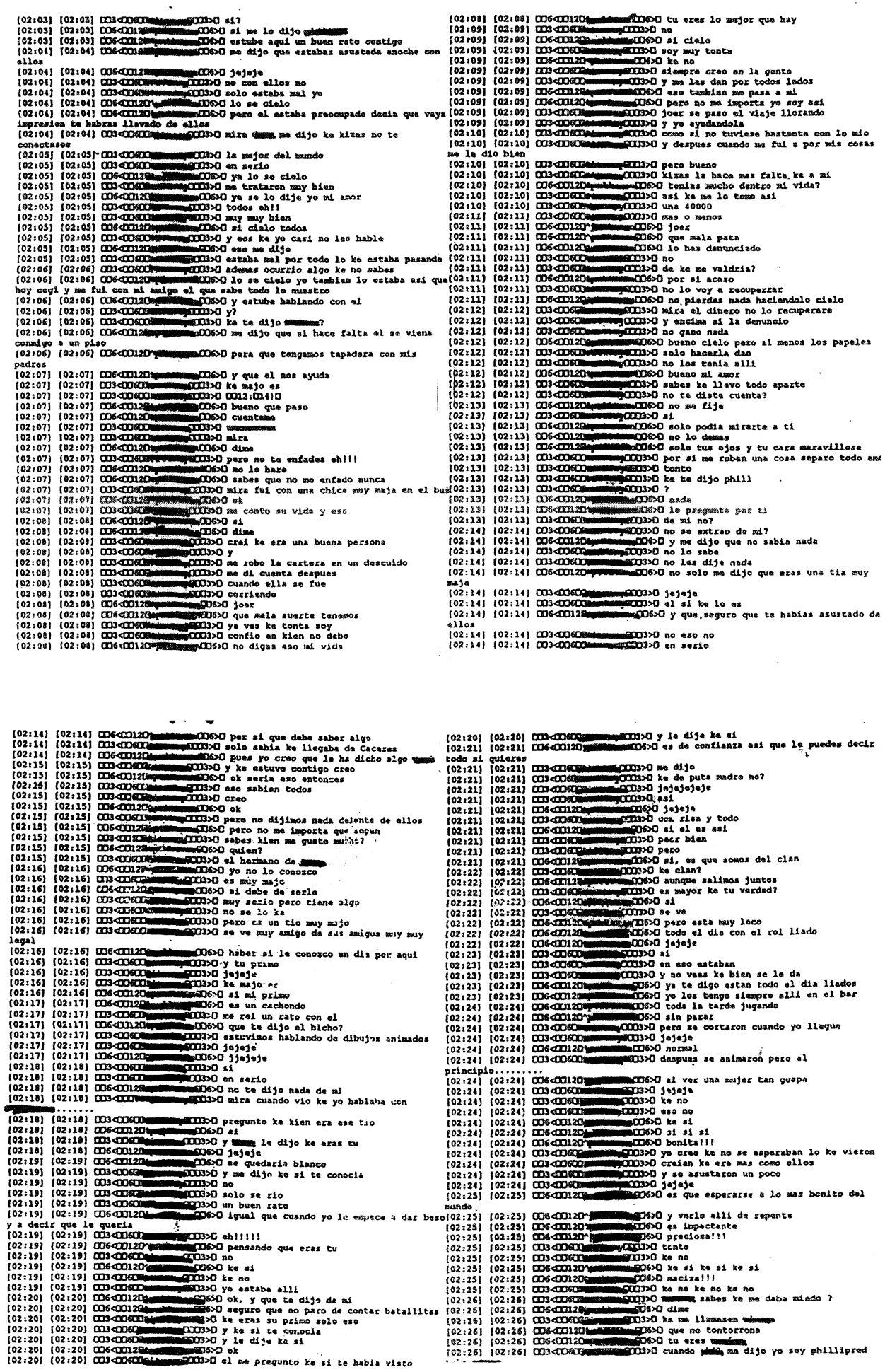

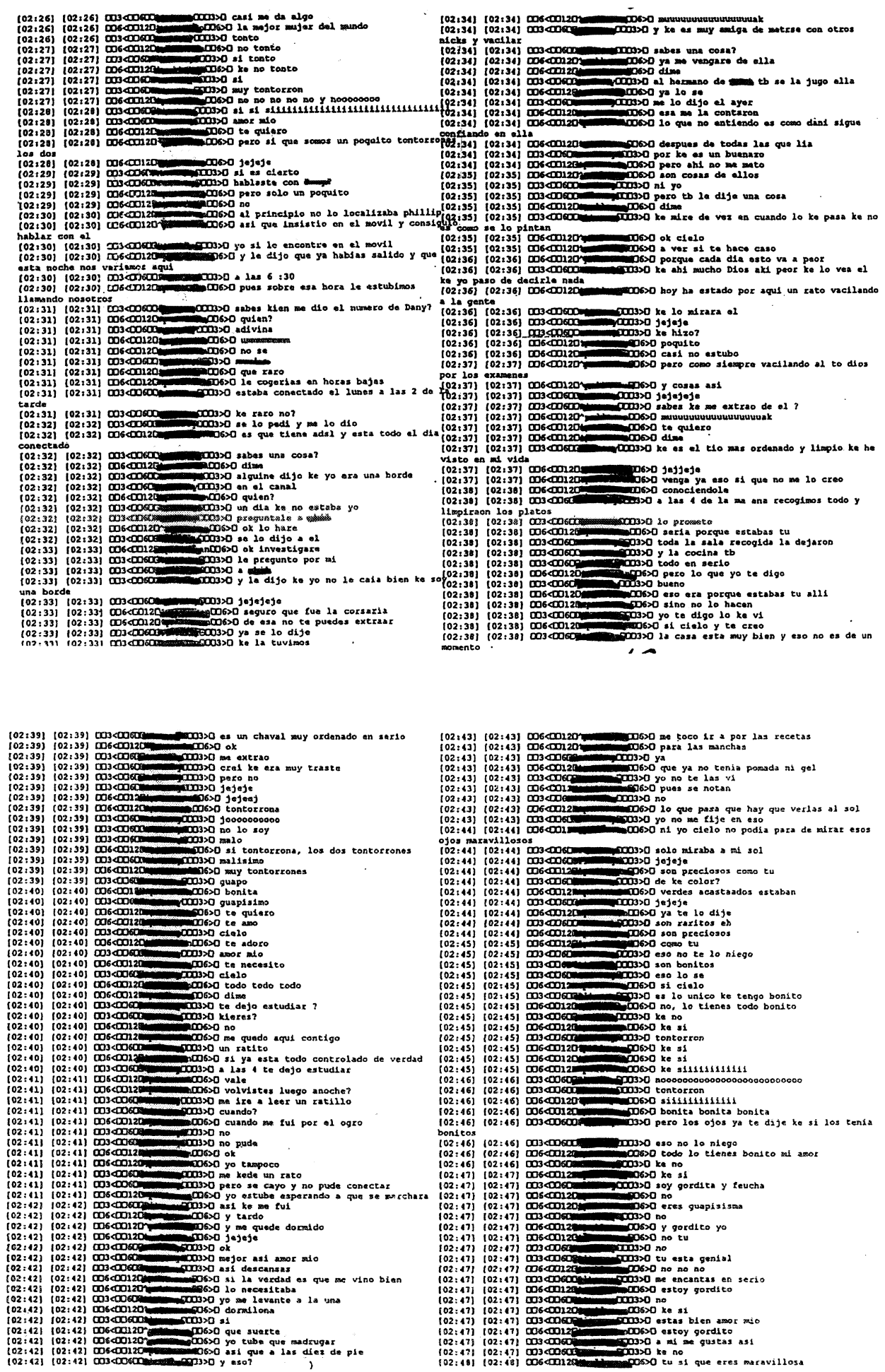

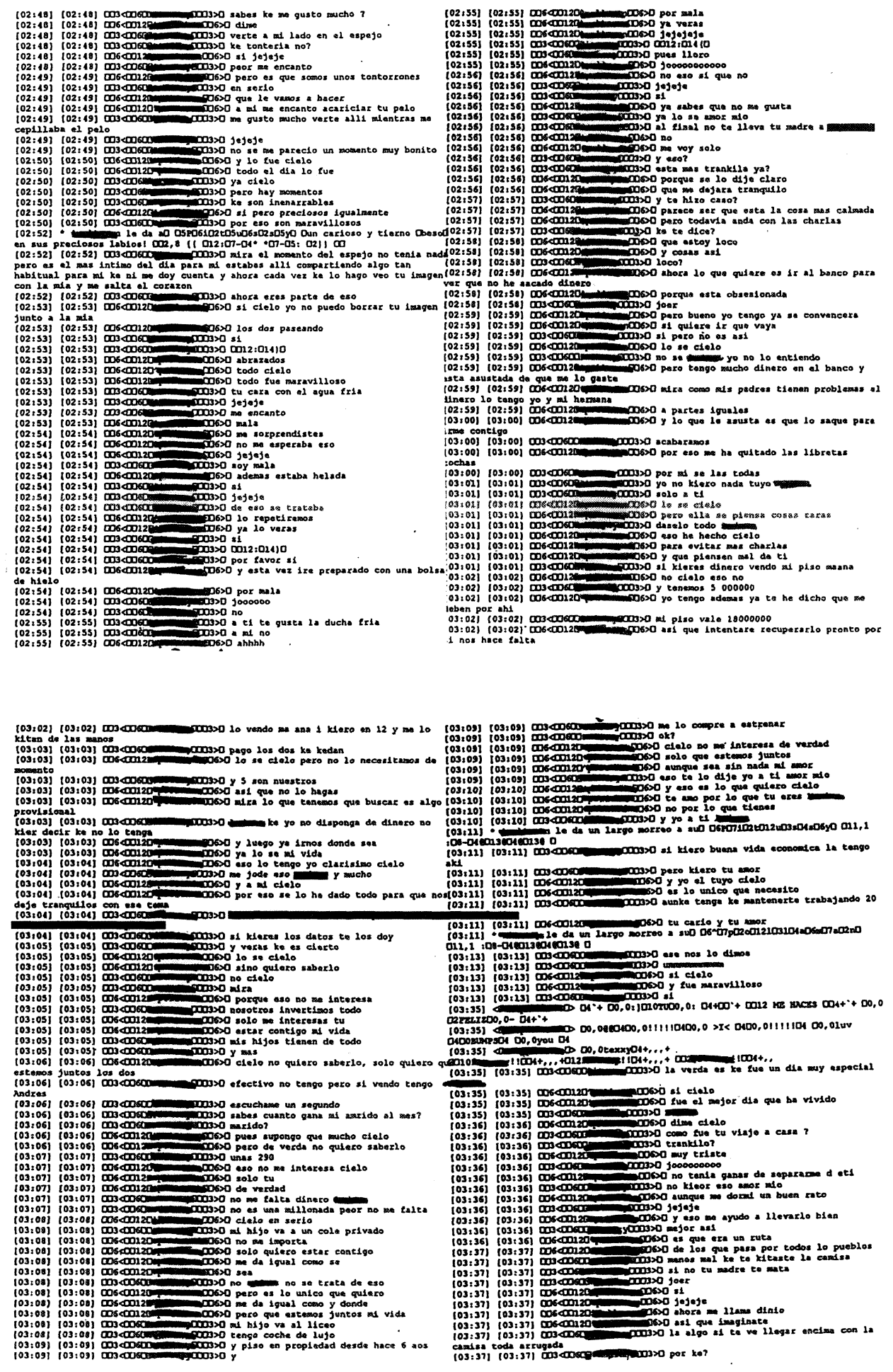

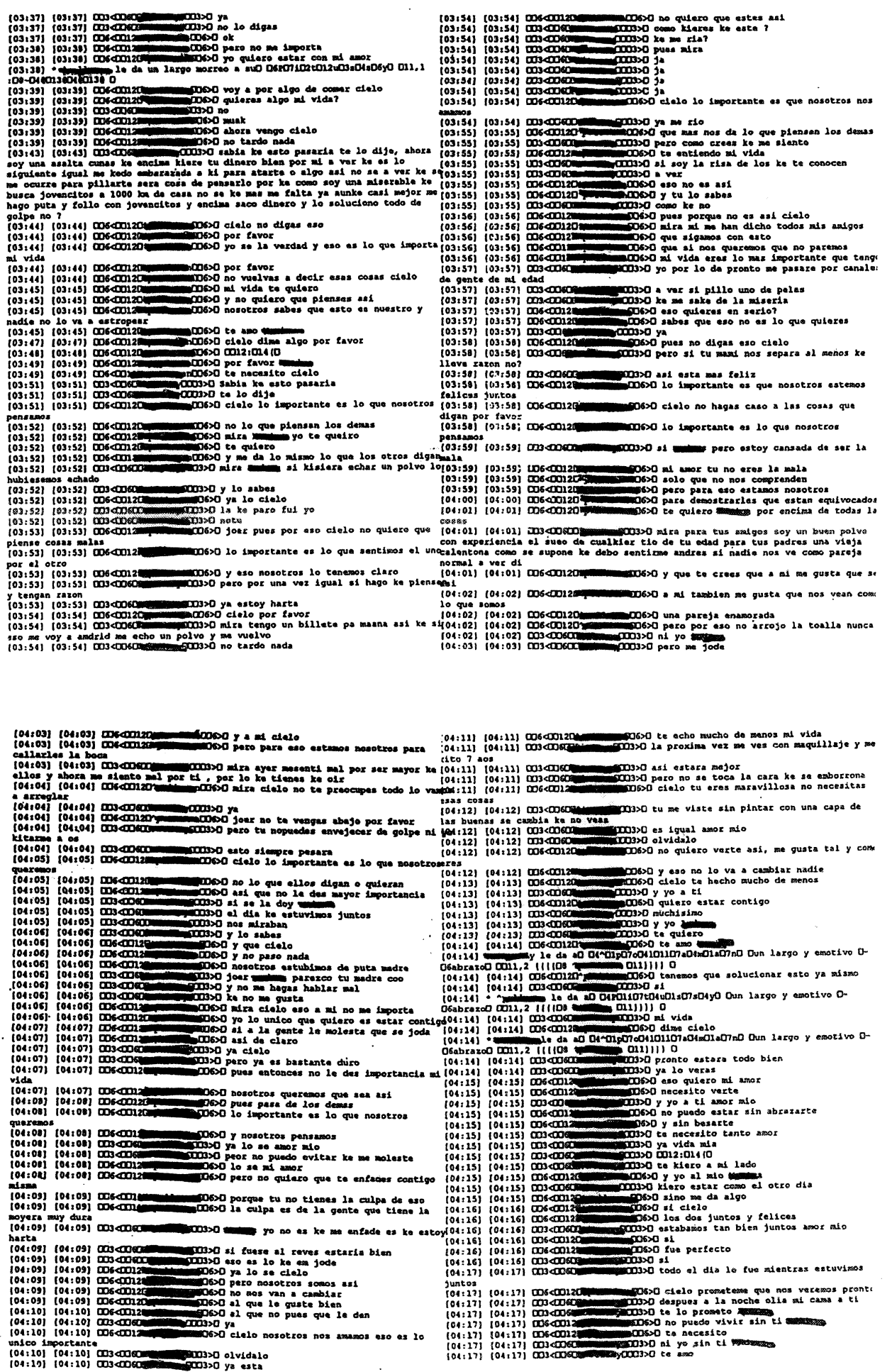

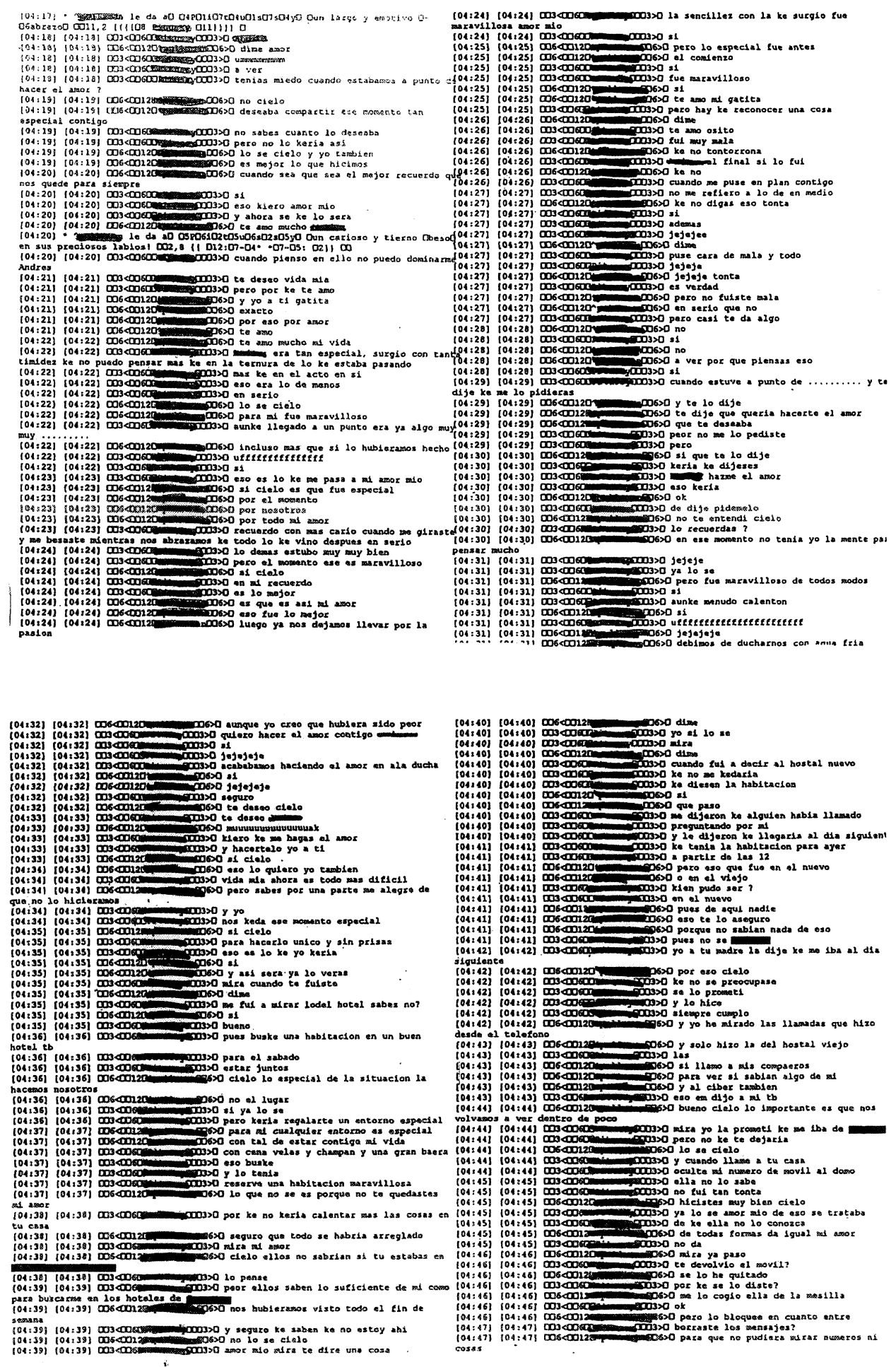

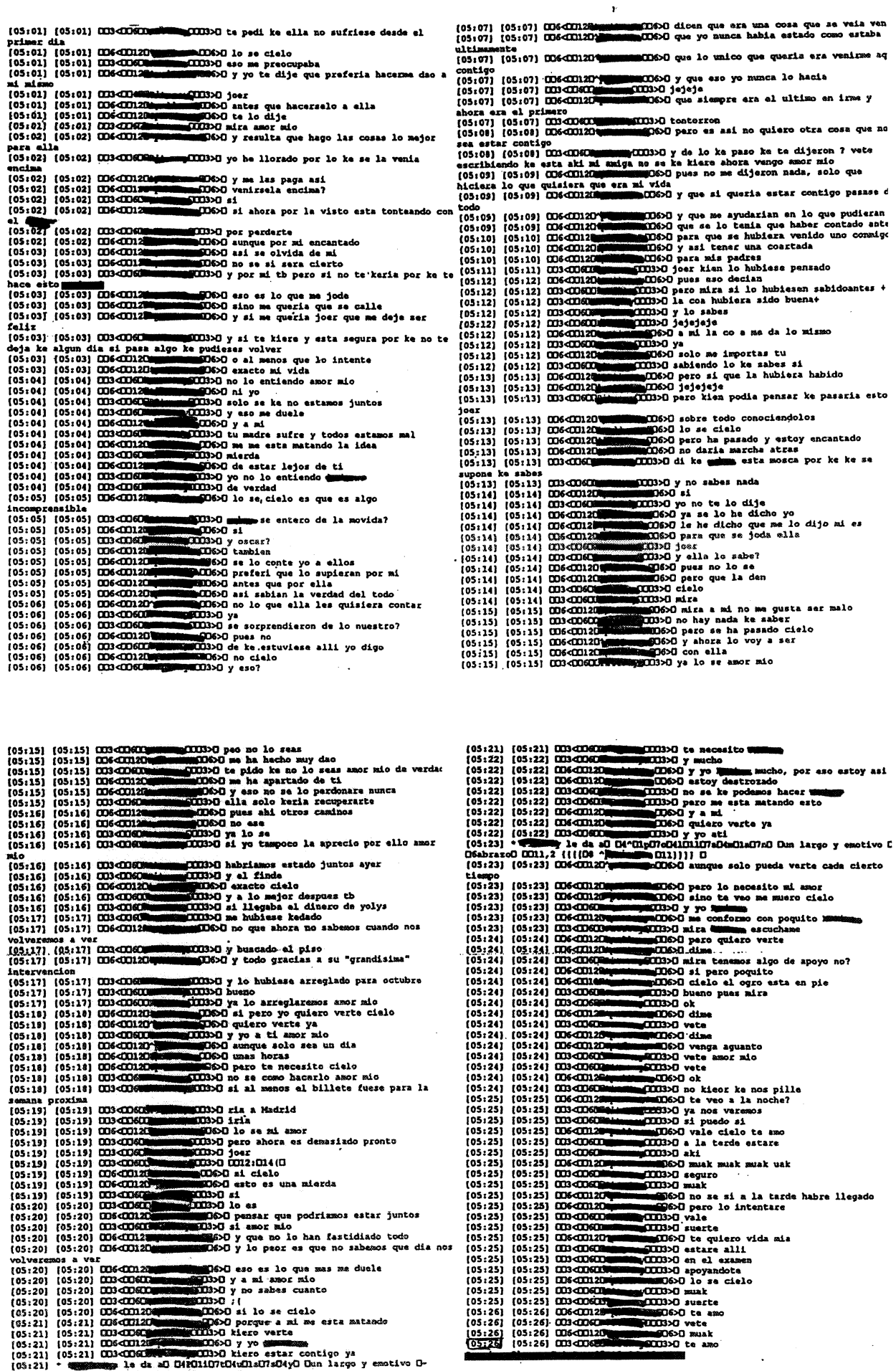